\title{
THE NEW DEAL CONSTITUTION IN EXILE
}

\author{
WILLIAM E. FORBATH ${ }^{\dagger}$
}

\section{INTRODUCTION}

Judge Douglas Ginsburg's evocative phrase "the Constitution-inExile" recalls the New Dealers' battle against the classical liberal Constitution fashioned in the Lochner era. For Ginsburg, the Supreme Court's embrace of the New Deal revolution cast the old Constitution into exile, its memory "kept alive by a few scholars who labor on in the hope of a restoration, a second coming of the Constitution of liberty." ${ }^{2}$ Until that day, Ginsburg and other restorationist scholars lament, the old Constitution's fundamental commitments - to limited national government and due regard for states' rights, to economic liberty and the rights of property-will remain forsaken. ${ }^{3}$ Constitutional culture will remain marred by a "double standard," vigilance in the name of personal and political liberty forever mocking an indifference to economic liberty. National government will remain a swollen and intrusive bureaucratic enterprise that

Copyright (C) 2001 by William E. Forbath.

$\dagger$ Angus Wynne, Sr. Professor of Civil Jurisprudence and Professor of History, University of Texas at Austin. This Essay is based on a paper presented at the Constitution in Exile conference hosted by the Program in Public Law at Duke University School of Law on October $5-7,2000$.

1. Douglas H. Ginsburg, Delegation Running Riot, Regulation, No. 1, 1995, at 83, 84 (reviewing DAVID SCHOENBRod, POWER Without Responsibility: How CONGRess Abuses the People Through Delegation (1993)).

2. Id.

3. See id. (listing as exiled "the doctrines of enumerated powers, unconstitutional conditions, and substantive due process, and their textual cousins, the necessary and proper, takings, and commerce clauses").

4. Stephen Macedo, The New Right v. The Constitution 40 (1986) ("The modern Court has erected a constitutional double standard by giving high place to 'personal rights' while neglecting economic rights that are at least as well founded in the Constitution."); Ellen Frankel Paul \& Howard Dickman, Introduction to LIBERTY, PROPERTY, AND THE FUTURE OF Constitutional Development 1, 3 (Ellen Frankel Paul \& Howard Dickman eds., 1990) ("Some see a 'double standard' in the Court's application of this deferential, rational basis test to challenged economic regulation, while it applies a much tougher test-of strict scrutinywhere legislation impinges on First Amendment rights or on equal protection rights guaranteed by the Fourteenth Amendment."). 
would find no place in the Constitution of liberty. This restorationist perspective has had a significant influence on the Rehnquist Court and elsewhere in the provinces of constitutional law. This conference ${ }^{5}$ itself is evidence that during the past decade the Constitution in exile has regained ground.

There is another Constitution in exile, however, one that also saw its fate sealed during the New Deal era. This second Constitution in exile is the lost sibling and rival of the restorationists' Constitution. Its architects in the Progressive Era called it the Constitution of "social citizenship." President Franklin D. Roosevelt called it the "general Welfare Constitution." Because the New Dealers ostensibly won the constitutional conflicts of the 1930s and 1940s, scholars assume that they know the constitutional outlook the New Dealers championed. But from the perspective of those decades, the New Deal constitutional legacy that is fought over today is a fractured one. That legacy enshrines the New Deal's expansion of national power, but not the new rights of national citizenship that warranted the expansion. Scholars remember that the New Dealers' conception of constitutional democracy demanded judicial restraint, but they forget that the New Dealers' constitutional outlook also laid affirmative obligations on the other branches of government.

The constitutional vision New Dealers championed against the old Constitution of (economic) liberty harbored no double standard between economic and noneconomic rights. The New Dealers answered the old Constitution's account of economic liberty with a new one. They held that all Americans had rights to decent work and livelihoods, social provision, and a measure of economic democracy, including rights on the part of wage-earning Americans to organize and bargain collectively with employers. ${ }^{8}$

Scholars forget that the allocation of interpretive and enforcement authority embodied in Carolene Products footnote four, ${ }^{9}$ which in 1938 sketched the post-Lochner Court's framework for judicial activism, had its origins in the political-constitutional thought of New Dealers in Congress and the Roosevelt administration. As these New

5. The Constitution in Exile conference hosted by the Program in Public Law at Duke University School of Law on October 5-7, 2000. (1999)

6. William E. Forbath, Caste, Class, and Equal Citizenship, 98 MicH. L. Rev. 1, 1 \& n.2

7. $I d$. at 69 .

8. See infra notes 83-84 and accompanying text.

9. United States v. Carolene Prods. Co., 304 U.S. 144, 152 n.4 (1938). 
Dealers articulated it, however, Congress's constitutional duties were not only to safeguard the constitutional bounds and fairness of social and economic legislation, but also to interpret and secure these new positive social and economic rights. By contrast, safeguarding the noneconomic rights inscribed in the Bill of Rights, as well as the rights of racial, ethnic, and religious minorities, would remain (or become) the special responsibility of the courts.

In championing this vision, the New Dealers carried forward a long tradition of congressional constitutional argument, interpretation, rights recognition, and precedent-making - what I shall call the political Constitution. ${ }^{10}$ This tradition has never been so thoroughly eclipsed as today. The present Court's outlook regarding the allocation of interpretive authority has been dubbed not mere judicial supremacy, but "judicial sovereignty." 11 The Court, Larry Kramer observes, "has revamped the doctrine [of judicial review] to eliminate the other branches' interpretive space and protect its exclusive custody of the Constitution."12 He continues,

What kind of republic removes its constitution [and participation by citizens and the elected branches in determining constitutional meanings] from the process of self-governing? Certainly not the one our Founders gave us. Is it one we prefer? The choice, after all, is

10. Often, this tradition focused on issues that courts and Congress agreed were matters for the legislative branch. The sustained and sometimes brilliant antebellum congressional constitutional arguments about the tariff are but one example. See KeIth E. WhitTington, CONSTITUTIONAL CONSTRUCTION 72-106 (1999) (discussing John Calhoun's argument that the protective tariff was unconstitutional but that the case was nonjusticiable, and showing how Congress arrived at a set of precedential understandings). On many other occasions, Congress saw itself sharing interpretive authority with the courts, and lawmakers both drew on judicial interpretations and also often disputed them. Rarely, as with the Kansas-Nebraska Act of 1854, Congress sought such interpretations. See DAVID M. POTTER, THE IMPENDING CRISIS, 18481861, at 271 (1976) (stating that the Kansas-Nebraska Act deferred to the courts on all questions regarding title to slaves in the territories). By the end of the nineteenth century, as the Court grew more active in drawing constitutional limits on congressional power, one finds the beginnings of a congressional critique of judicial constructions of Congress's Article I powers and of judicial assertions of interpretive authority regarding the scope of those powers.

Throughout, however, this tradition had focused chiefly on the powers of state versus federal government and on interbranch allocations of power. Individual rights arose more rarely as objects of direct congressional interpretation and enforcement. They loomed large, of course, during Reconstruction, and again, less familiarly, during debates over the "trusts." See Forbath, supra note 6, at 44-47 (documenting congressional discussion of Congress's affirmative duty to prevent corporations from infringing upon citizens' economic liberties and equal rights in market relations). In general, however, congressional constitutional discourse, until the New Deal, assumed that rights were secured indirectly by enforcing proper limits on government powers.

11. Larry Kramer, Foreword, 2000 Term: We, the Court, 115 HARV. L. REV. (forthcoming 2001) (manuscript at 10, on file with the Duke Law Journal).

12. Id. 
ours. The Supreme Court has made its grab for power. The question is, will we let them get away with it? ? $^{13}$

Although Kramer's plea is for the present, his brilliant historical reconstruction of "popular constitutionalism" ends with the 1830s. A century later, during the New Deal, the nation saw the last epic battles (thus far) waged on behalf of popular and legislative constitutional understandings against the Court's. It also saw profoundly important, but largely forgotten, constitutional conflicts unfold entirely outside the Court's purview, in Congress and in other public political arenas. Pondering Kramer's questions, scholars do well to recall these clashes, which display American "popular constitutionalism" in a more modern garb. They show popular, political constitutionalism at its basest as well as its best and reveal some of its complexities.

Until the New Deal, congressional constitutional debates had focused chiefly on the boundaries of state and federal, and judicial, executive and legislative powers; individual rights were secured indirectly by observing those boundaries. There were important exceptions. During Reconstruction, of course, Congress debated and enacted measures affirmatively safeguarding individual rights. Only with the New Deal, however, did one find elaborated in both Congress and the executive a constitutional vision demanding positive rights. At the heart of this outlook were the ideas of fundamental social and economic rights of national citizenship legislatively interpreted, enacted, and safeguarded, and of the adequacy of national power to meet this obligation of affirmative rights protection.

These social and economic rights are found in most of the world's constitutions; but they are foreign to contemporary American constitutional law and scholarship, and scholars assume they always have been. Even those rights that found reasonably robust statutory embodiment during the New Deal, like the right to organize, were not grounded on rights-protecting constitutional provisions. So if the old Constitution of liberty finds only a few reflections in contemporary doctrine, the traces of the New Deal's Constitution of economic freedom are even fewer; its exile is a colder one.

Scholars know too little of the New Deal constitutional vision and of the contests that sealed its fate. New Deal constitutional history is a scholarly battlefield, yet all the contending narratives agree

13. Id. (manuscript at 148). 
that the New Dealers secured the changes they sought. ${ }^{14}$ Twentiethcentury constitutional history has not fully recognized the parallels and precedents linking Reconstruction and the New Deal. First, when political-constitutional actors sought to enlarge the powers of Congress in the 1930 s as in the 1860 s, they did so in the name of a new and enlarged conception of national citizenship. Second, with the New Deal moment as with Reconstruction, the foes of change shaped the final outcome as deeply as did its champions. With Reconstruction, the story is familiar. By century's end, an accommodation between constitutional revolution and counterrevolution had been reached. Republicans as well as Democrats, courts, Congresses, and presidents alike had condoned Jim Crow and played some part in weaving segregation, lynch law, and mass disenfranchisement into the constitutional fabric of late-nineteenth- and early-twentieth-century America. In the case of the New Deal, constitutional scholars have not reckoned with the counterrevolution.

Unlike the New Deal battles over congressional power, which unfolded chiefly in the courts, the New Deal contests over the nation's asserted duty to enact new citizenship rights-whether through statute or constitutional amendment-took place in Congress, the executive branch, and the public sphere. The Constitution in Congress and other nonjudicial arenas is enjoying renewed scholarly interest. ${ }^{15}$ The non-Court-centered nature of this chapter of New Deal constitutional history should no longer obscure it from view. As David Currie observes, in every era "constitutional issues of the first importance" have been resolved in Congress without any judicial involvement, on

14. For a boldly revisionist account of the constitutional politics of the New Deal era, which nonetheless depicts the New Dealers' constitutional ambitions in conventional terms, see generally 2 BRUCE ACKERMAN, We tHE PEOPLE: TRANSFORMATIONS 279-344 (1998). For a painstaking recent effort to show that the New Deal constitutional changes arose through doctrinal evolution and changing judicial philosophies rather than in response to popular political pressure, the election returns, and Roosevelt's "Court-packing plan," see generally BARRY Cushman, Rethinking the New Deal Court: The Structure of a Constitutional REVOLUTION (1998). Like Ackerman, with whom he disagrees about almost everything else, Cushman also depicts the change New Dealers sought as enlarged national power, which they gained. See 2 ACKERMAN, supra, at 280-85 (arguing that the thrust of the "Roosevelt revolution" was "away from laissez-faire and toward activist government first at home and then abroad"); CUSHMAN, supra, at 11-32 (discussing the New Dealers' political and legal victories).

15. Examples of this scholarship include 1 BRUCE ACKERMAN, We THE PEOPLE: FOUNDATIONS (1991); 2 ACKERMAN, supra note 14; DAVID P. CURRIE, THE CONSTITUTION IN Congress, The Federalist Period, 1789-1801 (1997); CASs R. Sunstein, The PARTIAL CONSTITUTION (1993); MARK TUSHNet, TAKIng THE CONSTITUTION AWAY FROM THE COURTs (1999); WhitTInGTON, supra note 10; J.M. Balkin \& Sanford Levinson, The Canons of Constitutional Law, 111 HARV. L. REV. 963 (1998); Forbath, supra note 6; Kramer, supra note 11 . 
the basis of battles in the legislative and executive branches. ${ }^{16}$ It was a conservative counterrevolution in Congress between 1937 and 1945 that defeated the New Dealers' efforts to redefine national citizenship.

The nation's ongoing betrayal of Reconstruction, its acceptance of the disenfranchisement of the black South, and with it, of the majority of poor and working-class white southerners, meant that the "Solid South" was ruled by a planter and new industrial oligarchy. That oligarchy chose the bulk of the South's congressional delegation, and these Dixiecrat congressmen, in turn, formed a reactionary core at the heart of Roosevelt's liberal coalition. Bills creating broad federal rights to decent work and social provision enjoyed broad support in Congress. The Dixiecrats held the balance of power, however, and they thwarted these measures.

After the Court's "switch in time," a new political-constitutional configuration emerged. Instead of a Democratic president and Congress confronting a conservative Court, Roosevelt and the New Dealers confronted a conservative, anti-New Deal coalition of Republicans and southern Democrats in Congress. The old Constitution's solicitude for "States' sovereignty" and local "self-government" with plenary authority over "all domestic, social and racial relations," its regard for workers' liberty of contract and employers' property rights, and its hostility toward administrative and executive "usurpations" of lawmaking authority - all these doctrines found eloquent and effective advocates in the anti-New Deal congressional coalition. For the remaining eight years of Roosevelt's presidency, this coalition halted the engine of reform and stymied the New Deal's redefinition of national citizenship and the duties of government.

Constitutional scholars may gain a deeper critical purchase on today's Constitution from the historical perspective of the changes put forward and defeated during the later New Deal. Indeed, a body of historical scholarship has begun to emerge, examining the politicalconstitutional battles and initiatives of the later New Deal, partly with

16. CURRIE, supra note 15 , at 296 (concluding that the legislative and executive branches, not the judiciary, were most critical in interpreting the Constitution during the Federalist period). Especially in this case, where the claims of national rights and duties were most often countered by the claims of federalism and states' rights, scholars should not be surprised that the interpretative contests were intensely political, fought out in Congress rather than in the courts. See Larry D. Kramer, Putting the Politics Back Into the Political Safeguards of Federalism, 100 COLUM. L. REV. 215, 287-93 (2000) (arguing that Congress, since the early nineteenth century, has been a site of political battles in which state autonomy interests have been asserted and safeguarded). 
an eye to uncovering the roots of contemporary developments that distress many today: ${ }^{17}$ the widely shared assumption that "our constitutional tradition' is indifferent to 'economic inequality", ${ }^{18}$ the indifference of current antidiscrimination law to substantive inequality and its focus on classifications rather than subordinate classes $i^{19}$ and the resurgence of federalism in its least appealing aspect, with the Court not simply halting the expansion of the Commerce Clause, but declaring for the first time since 1883 that Congress lacks power under the Fourteenth Amendment to enact a law against discrimination. $^{20}$ This Essay examines the history of the liberal Constitution in exile with an eye to the light it sheds on this present season of liberal discontent.

\section{The Political Versus the Judicial Constitution AND the LEGISLATIVE Vision OF FUNDAMENTAL RighTS}

\section{A. The Wages of Resting Fundamental Rights on the Commerce Clause}

I begin with a great anomaly in twentieth-century constitutional development. Starting with the labor movement of the 1900s through the 1930s and continuing through the civil rights and women's rights movements of the 1940s through the 1970s, twentieth-century social movements demanded and gained recognition for important new rights.

17. For a sampling of this body of literature, see Forbath, supra note 6; William E. Forbath, Constitutional Change and the Politics of History, 108 YALE L.J. 1917 (1999); William E. Forbath, Constitutional Welfare Rights: A History, Critique and Reconstruction, 69 FORDHAM L. REV. 1821 (2001) [hereinafter Forbath, Constitutional Welfare Rights]; Risa L. Goluboff, The Thirteenth Amendment and the Lost Origins of Civil Rights, 50 DUKE L.J. 1609 (2001); Drew D. Hansen, The Sit-Down Strikes and the Switch in Time, 46 WAYNe L. REV. 49 (2000); James Gray Pope, Labor's Constitution of Freedom, 106 YALE L.J. 941 (1997) [hereinafter Pope, Labor's Constitution]; James Gray Pope, The Thirteenth Amendment Versus the Commerce Clause: Labor and the Shaping of the Post-New Deal Constitutional Order, 1921-1950, 102 Colum. L. REV. (forthcoming 2002) [hereinafter Pope, The Thirteenth Amendment] (manuscript on file with the Duke Law Journal).

18. Forbath, Constitutional Welfare Rights, supra note 17, at 1825 (quoting Lawrence Lessig, Fidelity as Translation, 65 FordHAM L. REV. 1507, 1509-10 (1997)).

19. See Adarand Constructors, Inc. v. Pena, 515 U.S. 200, 212-39 (1995) (holding that all racial classifications imposed by the government are subject to strict scrutiny); City of Richmond v. J.A. Croson Co., 488 U.S. 469, 486-511 (1989) (plurality opinion) (striking down an ordinance that required city construction contractors to subcontract a certain amount of their contracts to minority business enterprises, which were defined as businesses that are at least fifty-one percent "owned and controlled ... by minority group members").

20. See United States v. Morrison, 529 U.S. 598, 601-02 (2000) (striking down the Violence Against Women Act, which provided a civil remedy for victims of gender-motivated crimes of violence). 
They demanded these rights in the language and on the basis of the Reconstruction Amendments, but the Congresses that enacted the rights, the attorneys that defended the enactments, and the Courts that upheld them did so, overwhelmingly, on the basis of the commerce power. Accordingly, James Gray Pope points out in a major new study, the century's human rights movements provided a major impetus for the vast expansion of the commerce power, while the congressional powers that the movements themselves had championed-Congress's rightsprotecting powers-remained, in Pope's words, "unrescued from nineteenth-century limitations." 21

Until the 1990s this anomaly did not seem practically significant, because from the 1937 "switch in time" onward, and particularly in its landmark decisions of the 1960s, the Court was willing to interpret and enlarge the commerce power to accommodate Congress's rightsprotecting initiatives. Today, however, the anomaly has become glaring. The current Court called a halt to the commerce power's endless expansiveness in United States v. Lopez $z^{22}$ and cemented its new limits in United States v. Morrison. ${ }^{23}$ Because the law at issue in Morrison was a civil rights statute, ${ }^{24}$ one might think it would fall within Congress's authority to enforce the Fourteenth Amendment. But no. At the same time that it has reasserted judicially enforceable limits on the commerce power, the Court has reached back into the nineteenth century to affirm-indeed, to stiffen - the stringent limits on Congress's Fourteenth Amendment powers announced in the 1883 Civil Rights Cases. ${ }^{25}$

21. Pope, The Thirteenth Amendment, supra note 17 (manuscript at 9).

22. 514 U.S. 549, 551-52 (1995) (holding that Congress exceeded its powers under the Commerce Clause in passing the Gun-Free School Zones Act of 1990).

23. 529 U.S. at 601-02 (holding that the Violence Against Women Act, which provided a civil remedy for victims of gender-motivated crimes of violence, exceeded Congress's legislative powers).

24. Violence Against Women Act of 1994, Pub. L. No. 103-322, 108 Stat. 1902 [hereinafter VAWA] (invalidated in part in Morrison, 529 U.S. at 601-02).

25. 109 U.S. 3 (1883). In casting the challenged provision of VAWA as an exercise of its Fourteenth Amendment power, Congress rested its authority not on the irrelevance of the state action doctrine announced in the 1883 opinion, but rather on a voluminous record showing that the states were failing to provide women equal protection of the laws in the context of gendermotivated violence. Morrison, 529 U.S. at 614. As it had in the Civil Rights Cases, the Morrison Court concluded that the challenged provision was unconstitutional because it reached beyond culpable state officials to sanction private conduct. In the 1883 decision, however, the Court specifically held that the 1875 statute under attack was not "predicated" on "any supposed or apprehended violation of the Fourteenth Amendment on the part of the States." The Civil Rights Cases, 109 U.S. at 14. Thus, while the Civil Rights Cases insisted that Section 5 legislation must be "corrective of [a] constitutional wrong committed by the States," that opinion left open the possibility that federal regulation of private parties was allowable under Section 5 as long as that regulation is properly "corrective" of state action "adverse to the rights of citizens sought to 
As Robert Post and Reva Siegel remark, "[o]ne cannot reason about the scope of the national government's authority to enforce civil rights without addressing the history of the second Reconstruction," ${ }^{26}$ the civil rights movement that Brown v. Board of Education ${ }^{27}$ helped spawn, and Congress's response to that movement with the enactment of the Civil Rights Act of $1964{ }^{28}$ Yet that is precisely what the Supreme Court did in Morrison, by resting its decision about the scope of Congress's authority to enforce civil rights squarely on late-nineteenthcentury precedent-precedent that is redolent of the dominant racial and political values of the era. ${ }^{29}$

The Morrison Court could comfortably do so, because of what Post and Siegel dub the "jurisdictional' compromise of the 1960s," ${ }^{30}$ when the Court upheld the Civil Rights Act of 1964 on Commerce Clause grounds alone. ${ }^{31}$ The Court shied away from a confrontation with its Gilded Age Section 5 precedents and chose instead to build on the case law of the New Deal settlement, ceding broad legislative powers under the Commerce Clause. This "fixed a fateful pattern," "progressively obscuring" the relationship of federal civil rights law to Section 5 and, thereby, the shape and reach of Section 5 authority. ${ }^{32}$ Now that relationship may be defined by a Court majority whose own civil rights outlook harks back to the Gilded Age.

be protected by the Fourteenth Amendment." Id. at 13. The Morrison Court's insistence that the Civil Rights Cases (and later cases) stand for a per se rule against sanctioning private actors under Section 5, and its alternative holding that Congress's extensive findings of adverse state action regarding the policing and prosecution of gender-motivated violence were not sufficient to warrant the remedy Congress fashioned, combined to virtually close off that possibility. Morrison, 529 U.S. at $621,614$.

26. Robert C. Post \& Reva B. Siegel, Equal Protection by Law: Federal Antidiscrimination Legislation After Morrison and Kimel, 110 YALE L.J. 441, 486 (2001).

27. 347 U.S. 483 (1954).

28. Civil Rights Act of 1964, Pub. L. No. 88-352, 78 Stat. 241; Post \& Siegel, supra note 26, at 486 .

29. Post and Siegel point out that since Brown, the Court's and Congress's views of the reach of civil rights law into traditionally local and "private" domains has been transformed, although without any clear recasting of Section 5 doctrine. Post \& Siegel, supra note 26, at 489. Ignoring this transformation, the Morrison Court embraces the Court's Gilded Age civil rights jurisprudence, which linked protecting the domain of "domestic law" to defending the naturalness of racial and gender hierarchies and a "racialized conception of the freedom to associate." Id.

30. Id. at 443 .

31. Heart of Atlanta Motel, Inc. v. United States, 379 U.S. 241, 261 (1964) (“[T]he action of the Congress in the adoption of the Act as applied here to a motel which concededly serves interstate travelers is within the power granted it by the Commerce Clause."); Post \& Siegel, supra note 26 , at 443 .

32. Post \& Siegel, supra note 26 , at 448. 
This 1960s jurisdictional compromise, Pope reminds us, was in turn rooted in events that took place decades earlier..$^{33}$ The first jurisdictional compromise was the decision on the part of Senator Wagner and his staff of New Deal lawyers to rest the National Labor Relations Act (NLRA) ${ }^{34}$ popularly known as the Wagner Act, on the commerce power rather than on the Thirteenth or Fourteenth Amendment. By grounding the Act thus and persuading the Court in $N L R B$ v. Jones \& Laughlin Steel Corp. ${ }^{35}$ to do likewise, Wagner and the government attorneys enlarged the domain of legislative power and policymaking, but they left labor's hard-won rights "to the shifting outcomes of ordinary politics." ${ }^{36} \mathrm{Had}$ they rested the Act instead on the Thirteenth or Fourteenth Amendment, the Court would have had to confront the constitutional rights-based arguments for the labor rights that the Act protected, thereby restraining future Congresses and Courts from diminishing and balancing away those rights so freely. The upshot also might have been a great enlargement of Congress's constitutional rights-protecting authority, beyond its nineteenth-century limitations, and consequently a greater likelihood that the broad antidiscrimination statutes of the 1960s could have rested comfortably on the Reconstruction Amendments.

So, even before the conservative counterrevolution thwarted their efforts, the New Dealers seem to have decided against constitutionalizing the new rights they championed. Pope condemns this choice, contending that the Thirteenth Amendment was the proper basis for the freedoms labor sought and the basis labor preferred. ${ }^{37}$ The New Deal lawyers and lawmakers chose to rest the Wagner Act on the Commerce Clause, in his view, because their professional interests were not "those of the people." ${ }^{38}$ They wanted to expand the constitutional power of government policymakers, experts, and social engineers, not the rights of workers. ${ }^{39}$

In fact, the New Dealers' constitutional choices were more constrained, more complex, and more principled than Pope suggests. The

33. See Pope, The Thirteenth Amendment, supra note 17 (manuscript at 11-12).

34. National Labor Relations Act of 1935, Pub. L. No. 74-198, 49 Stat. 449.

35. 301 U.S. 1, 33 (1937).

36. Pope, The Thirteenth Amendment, supra note 17 (manuscript at 99).

37. Id.

38. Id.

39. Id. (manuscript at 259) ("In class terms ... the constitutional revolution of the 1930s represented the triumph ... of what might be called the 'knowledge class' over the previously dominant business class. The role of the working class was to provide the foot soldiers for change."). 
progressive tradition-associated with thinkers and reformers like John Dewey, Florence Kelley, Louis Brandeis, Felix Frankfurter, and Robert Wagner-was Janus-faced. Progressives spoke of gaining social control over economic institutions and market relations. But "social control" was deeply ambiguous. The term could mean social and economic citizenship and democratic control: democratic, not juridical, construction of the ground rules of economic life and democratization of workplaces and other "private" institutions through unions and other forms of association. Or social control could mean what Pope highlights: control by public and private experts, social engineers, scientific managers, and policymakers. Generally, it meant some combination of both, and different progressive thinkers-or even the same thinkers in different moments-envisioned different melds of the two ideals. ${ }^{40}$ Common to both was the conviction that rights should be understood in terms of social context and social policy, redeemed and defended through legislative deliberation and enactment, and kept out of the hands of legalists and formalists. Thus a deeply democratic progressive like Wagner could believe that the rights to strike, organize, and bargain collectively through unions were fundamental rights of national citizenship, and yet not want to embed them in the Constitution's rightsprotecting provisions. The latter only would authorize and encourage the courts to delineate the boundaries of these newly enacted rights, and courts would do so against a backdrop of inherited and hostile judicial constructions of those very provisions. Pope slights this complexity, but he is right that understanding the anomalous status-the apparent lack of constitutional mooring-of so many of the rights Americans gained in the twentieth century must begin with these events. Understanding them, in turn, requires canvassing the general contours of New Deal rights discourse.

40. Compare, e.g., Louis Brandeis, How Far Have We Come on the Road to Industrial Democracy? An Interview, LA FOLLETTE's WKLY. MAG., May 24, 1913, reprinted in LOUIS D. BRANDEIS, THE CURSE OF BIGNESS 43-47 (Alfred Leif ed., 1934) (emphasizing worker participation in industrial governance), with LOUIS D. BRANDEIS, THE SOCIAL AND ECONOMIC VIEWS OF Mr. JUSTICE BRANDEIS 391-93 (Alfred Kief ed., 1930) [hereinafter BRANDEIS, SOCIAL AND ECONOMIC VIEWS] (discussing the social gains that workmen receive from scientific management); compare HeRbert Croly, THE Promise of AMERICAN Life (1963) (a Progressive classic in which the elitist and managerial strains of progressivism loom large), with Herbert Croly, Progressive Democracy (1914) (a second classic, in which the democratic strains are dominant). 


\section{B. The New Dealers' Constitution of Social Citizenship}

1. The Substance. Constitutional politics involves reinterpreting and revising our fundamental commitments and arriving anew at considered popular judgments about the rights of citizens and the duties of government. The New Deal constitutional moment legitimated the powers of the national regulatory and welfare state. It also saw a sustained effort to redefine the duties of government and the social and economic commitments of the nation to its citizens. The contours and contents of this redefinition are clarified by contemporary nonjudicial texts. ${ }^{41}$ These texts, in turn, reveal the rival constitutional vision put forward by the foes of the old Court and its Constitution as Carter v. Carter Coal Co., ${ }^{42}$ A.L.A. Schechter Poultry Corp. v. United States, ${ }^{43}$ and the other anti-New Deal decisions were handed down, and Jones \& Laughlin and the other Wagner Act cases made their way to the Court.

On the hustings, in radio addresses, and in more sustained debates, speeches, and writings, the lawmakers and the president argued not simply that Congress had the power under the Constitution, rightly understood or amended, to regulate agriculture, industry, and labor. They argued that citizens had fundamental economic and social rights under the Constitution, rightly understood or amended; and Congress, therefore, had the duty to exercise its power to govern economic and social life in a way that sought to secure those rights. Making these arguments, New Dealers drew on a half-century-old tradition of constitutional discourse that I have dubbed the "social citizenship" tradition. ${ }^{44}$ It provided them not only a rights rhetoric, but also a constitutional narrative, modes of interpretation, and conceptions of the allocation of interpretive authority.

The narrative, of course, was about a "changing," "living" Constitution; more specifically, it was about constitutional change and continuity in an industrialized America. Some variants of the narra-

41. To discern the "constitutional mandate" arising from key elections like those of 1866 and 1936, Ackerman urges us to study constitutional discourse outside the courts in "congressional committee reports, presidential proclamations, and party campaign platforms with the same care that lawyers usually reserve for Supreme Court opinions." Bruce Ackerman, Higher Lawmaking, in RESPONDING TO IMPERFECTION: THE THEORY AND PRACTICE OF CONSTITUTIONAL AMENDMENT 63, 74 (Sanford Levinson ed., 1995).

42. 298 U.S. 238 (1936).

43. 295 U.S. 495 (1935).

44. Forbath, supra note 6, at 1 . 
tive underscored the closing of the frontier; others the end of petty proprietorship in agriculture and industry; still others, more abstractly, the new interdependence of both individuals and local, state, and regional economies as the reason that the national government now must undertake new obligations. Some claimed that with the Reconstruction Amendments, the national government had assumed the duty to secure citizens' economic liberty and equality of rights and opportunities, but that industrialization and the concentration of wealth and power in giant corporations had transformed the social meaning of economic freedom and, with it, the kinds of laws and governmental machinery this duty entailed. Others claimed that securing equal rights in the pursuit of work, opportunity, and a share of the nation's wealth had been a defining purpose and duty of government since the Founding; but now neither the "separate State[s]" nor equal enjoyment of the common law rights of contract and property could fulfill that duty. ${ }^{45}$ Rather, it had become an "interstate subject" and a positive national obligation. "[I]t was to conserve this necessary legislative power that the welfare provision of the Virginia plan and the general-welfare clause was designed."

In Congress, after Schechter in May 1935, and, with growing intensity, after Carter Coal in May 1936, proposals for constitutional amendments multiplied. " $[\mathrm{H}]$ aving in mind the Supreme Court's [National Recovery Administration] decision [Schechter]," scores of New Deal congressmen would declare that "the time has come to extend the Bill of Rights to embrace such guarantees as 'the right to honest work,' an industry-wide 'minimum standard of hours, wages, and fair competition,' and the like." 48

Some amendment advocates said these rights were already implied, but an amendment would "unmistakably establish the right of the people to have both an industrial democracy and a political democracy." ${ }^{49}$ Others chose to depict the constitutional conflict between the New Deal and its adversaries on the Court and in the Republican party as "one of the great climacterics of the world, an era of change

45. 79 CONG. REC. 13,914 (1935) (statement of Rep. Lewis).

46. Id.

47. See Jane Perry Clark, Some Recent Proposals for Constitutional Amendment, 12 WIs. L. REV. 313, 314 (1937) ("[D]iscussions of the possibility of amendment have become common ....").

48. 79 CONG. REC. 14,212 (1935) (statement of Rep. Maverick).

49. Id. at 8470 (statement of Rep. Hildebrandt). 
in thought and policy" ${ }^{, 50}$ regarding the duty and function of government. "[I]t cannot be said," one senator conceded, "that the object of the founders of our Government was to guarantee the economic independence or economic security of the individual citizen." ${ }^{51}$ But the transformation of a "pioneer community" into a "highly mechanized and industrialized" nation gradually had changed citizens' conceptions of liberty and the proper relation between government and individual responsibility. ${ }^{52}$ The Great Depression and the electoral and judicial contests over the New Deal had crystallized these changes. By 1936, as this senator put it, the "well-defined, seasoned, sober second thought of the citizenry" had emerged. "Economic or social insecurity due to old age.... infirmity, illness or injury .... [or] unemployment" were injuries to constitutional liberty rightly understood, and the national government must be authorized and obliged to attack them. ${ }^{54}$

2. The Allocation of Interpretive Authority and the Roots of Footnote Four. Accompanying these substantive ideas was a set of views about the allocation of interpretive and enforcement authority. It was clear that "[s]omebody should determine whether an act of Congress is repugnant to the Constitution." Only on rare occasions, however, and only in respect of certain constitutional provisions was the Court the proper somebody. The Constitution was a "statesman's document," whose general "abstract phrases" were best "interpreted in the legislative laboratory where and when the statute [was] being made. ${ }^{, 56}$ Until the late nineteenth century, New Dealers pointed out, the houses of Congress, the president, and the people at the polls were (almost) the sole wielders of a constitutional veto over congressional statutes. ${ }^{57}$

Now that Congress had affirmative obligations as well as duties of self-restraint in respect of rights protection, this allocation of interpretive authority to Congress was all the more imperative. The right

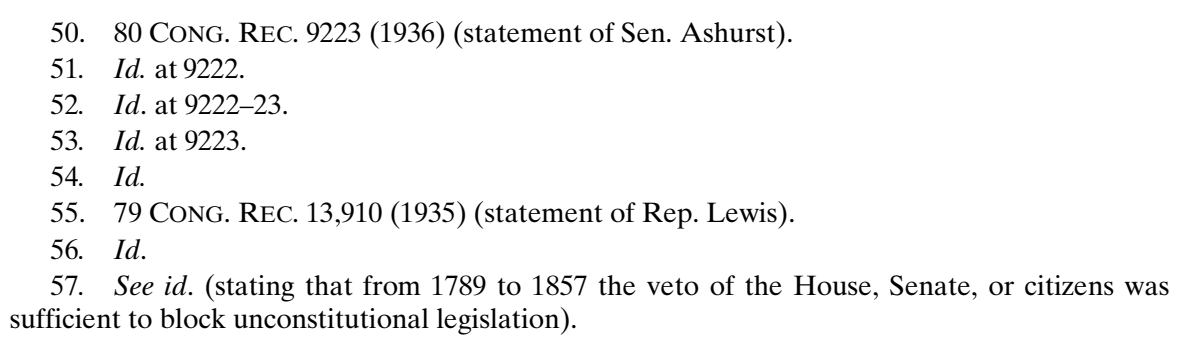


to work, "the equal right ... to a share of the Nation's employment asset"- these were modern rights that the Constitution, rightly understood, both authorized and obliged Congress to protect, ${ }^{58}$ and advocates insisted on the right of Congress "to determine for itself the meaning of [the Constitution's general rights-protecting] provisions" in recognizing a modern social right to work. ${ }^{59}$ To those who insisted on "the traditional legal habit of looking upon rights as negative," these advocates first objected that seventeenth- and eighteenthcentury ideas had imparted a rigidity that ill-served "legislators who must implement" the Constitution. ${ }^{60}$ Several traditional constitutional rights already

actually require government to take very positive action indeed... [entailing] all the involved and expensive machinery for the administration of civil and criminal justice.... In terms of mechanism and trained personnel, a system of social insurance is child's play in comparison with the system that gives effect to due process of law. ${ }^{61}$

To be sure, social rights did not lend themselves to judicial enforcement, but judicial enforcement was not always the proper test of a right.

What rights, then, were appropriately safeguarded by a vigorous judiciary? Here, as early as 1935, one finds New Dealers in Congress and the liberal academy outlining the "preferred position" idea we associate with the first paragraph of Carolene Products footnote four. ${ }^{62}$ "Many of the [Bill of Rights'] prohibitions concern concrete and specific subjects ...." ${ }^{63}$ For this reason, and no doubt other more substantive ones, even those who favored measures curtailing the Court's power of review suggested that "[j] urisdiction might well be left in the courts to pass upon the validity of acts relating to such fully described subjects. In the case of such specific prohibitions the courts themselves can feel a real confidence in their opinions. ${ }^{\circ 4}$

\footnotetext{
58. Id. at 13,914 .

59. Full Employment Act of 1945: Hearings Before a Subcomm. of the S. Comm. on Banking and Currency on S. 380, 79th Cong. 1249-59 (1945), quoted in Forbath, supra note 6, at 75.

60. Id. at 1252-53, quoted in Forbath, supra note 6, at 75.

61. Id. at 1252-53, 1255, quoted in Forbath, supra note 6, at 75.

62. United States v. Carolene Prods. Co., 304 U.S. 144, 152 n.4 (1938).

63. 79 CONG. REC. 13,916 (1935) (statement of Rep. Lewis).

64. Id.
} 
Many put the matter in more substantive terms, anticipating some of footnote four's other benchmarks. "The great and serious objection to any change in 'due process' is that it has been a bulwark against the infringement of civil liberties by both Congress and the State legislatures." ${ }^{65}$ Likewise, the Fourteenth Amendment in judicial hands had sometimes proved "useful in stemming the tides of prejudice manifested in [certain state] legislation." ${ }^{, 66}$ Accordingly, proposed amendments and bills limiting judicial review were crafted to leave intact Fourteenth Amendment-based review "as applied to other than statutes regulating economic matters." ${ }^{67}$ In the same vein, proposed amendments empowering Congress to safeguard labor rights contained provisions that insulated from due process scrutiny "legislation by the Congress or by the several states on any of the subjects referred to [in the substantive sections of the Workers' Rights amendment $]$. . . except as to the methods or the procedure for the enforcement of such legislation.", 68

3. Roosevelt's Popular Constitutionalism. From the first New Deal onward, the president set himself a task of constitutional narration and interpretation, to elaborate and win the nation's support for a "re-definition of [inherited constitutional] rights in terms of a changing and growing social order." ${ }^{\circ 9}$ Thus, Roosevelt situated those rights in terms of their eighteenth-century meaning. Quoting Jefferson, he evoked an agrarian past when America had "no paupers. The great mass of our population [was] of laborers ... [and m] ost of the laboring class possess[ed] property...." Fo For these smallholdercitizens, the rights "involved in acquiring and possessing property," together with the ballot and the freedom to live by one's "own lights," ensured liberty and equality. ${ }^{71}$ Well into the nineteenth century, Roosevelt's grand rights-interpreting narrative continued, roughly comparable conditions endured. If industrial concentration and industrial depressions tore away from many Americans the kind of eco-

65. Clark, supra note 47 , at 323.

66. Id. at $323 \mathrm{nn} .35-37$.

67. Id. at 325 .

68. Id. (quoting S.J. Res. 3, 74th Cong. § 2 (1936)).

69. Franklin D. Roosevelt, New Conditions Impose New Requirements upon Government and Those Who Conduct Government, Campaign Address at the Commonwealth Club, San Francisco, Cal. (Sept. 23, 1932), in 1 Franklin D. Roosevelt, The Public PaPers AND ADDRESSES OF FRANKLIN D. RoOSEVELT 742, 753 (Samuel I. Rosenman ed., 1938).

70. Id. at 745 .

71. Id. at 746 . 
nomic independence and decent work that underwrote republican citizenship, still the frontier remained open, land remained cheap, and the scale of commerce and production in much of the nation remained small and local. ${ }^{72}$ So, for almost a century, in pre-industrial and industrializing America, the "old and sacred possessive [common law] rights" of property and labor, ${ }^{73}$ enshrined in the Court's Constitution, retained much of their social meaning for the "welfare and happiness" of ordinary Americans.

By the end of the nineteenth century, however, the frontier had closed, free land was "no more," and "our industrial combinations had become great uncontrolled and irresponsible units of power within the State." 74 These new conditions robbed the old rights of their original meaning. All Americans understood this social-historical sea change, Roosevelt suggested, and all had access to the insight that new contexts demanded new meanings lest old texts be distorted and old values lost. ${ }^{75}$

As the administration's clashes with the Court intensified, and the administration's foes assailed Roosevelt and the New Deal for subverting the Constitution, Roosevelt turned to the legacy of popular constitutionalism, with its emphasis on the people's and popular leaders' interpretive authority. The Constitution, he reminded Americans, was a "layman's document." Repeatedly, in times of crisis and change, the "lay rank and file" interpreted the Constitution for themselves and they "ultimately ... had their way."

Thus did Roosevelt and congressional New Dealers construe their overwhelming electoral victory of 1936 as a mandate for a new constitutional philosophy. A mature industrial society could not be governed by a laissez-faire Constitution, insulating industry and finance from the modern claims of liberty and equality. America needed an "economic constitutional order." ${ }^{78}$ The terms of our basic rights "are as old as the

72. $I d$.

73. Franklin D. Roosevelt, Message to the Congress Reviewing the Broad Objectives and Accomplishments of the Administration (June 8, 1934), in 3 FRANKLIN D. RoOsEVELT, THE PUblic PAPERS AND ADDRESSES OF FRANKLIN D. RoOSEVELT 287, 292 (Samuel I. Rosenman ed., 1938).

74. 1 RoOSEVELT, supra note 69 , at 749 .

75. 3 RoOSEVELT, supra note 73, at 291-92.

76. Franklin D. Roosevelt, The Constitution of the United States Was a Layman's Document, Not a Lawyer's Contract (Sept. 17, 1937), in 6 FrANKLIN D. RooseVELT, THE PUbLIC PAPERS AND ADDRESSES OF FRANKLIN D. RoOSEVElT 359, 359 (Samuel I. Rosenman ed., 1941).

77. Id. at 365 .

78. 1 RoOSEVELT, supra note 69 , at 752 . 
Republic," ${ }^{, 79}$ but new conditions demand new readings. "Every man has a right to life," Roosevelt proclaimed, and a "right to make a comfortable living." "The "government," he went on, "formal and informal, political and economic, owes to everyone an avenue to possess himself of a portion of [the nation's wealth] sufficient for his needs, through his own work." ${ }^{\text {11 }}$ A right "to make a living-a living decent according to the standard of the time" was at the heart of the new interpretation of the constitutional promise of liberty that Roosevelt had expounded throughout the 1936 election campaign. ${ }^{82}$

\section{New Deal Rights in Congress and the Court: Strategies and Principles}

Thus, from the vantage point of 1935-37, the New Deal endeavor was not simply expanding national legislative authority, although that is the goal we associate with this constitutional moment; the endeavor also embraced enlarging the rights of citizens and the duties of government. In public political discourse, New Dealers cast the changes they sought as fundamental rights reinvigorating the Constitution's promise of equal citizenship by reinterpreting it. Yet, as a matter of statutory drafting and litigation strategy, they consistently relied on congressional power clauses, not on rights-affirming clauses of the Constitution. The New Deal Constitution took this odd and, from today's perspective, lamentable form not for lack of constitutional commitment, but because of a specific conception of the rights at issue and the appropriate allocation of interpretive and enforcement authority regarding them, combined with a strategic concern about judicial interpretation and enforcement.

Only with the Wagner Act was the issue of the New Deal rights' constitutional basis joined. ${ }^{83}$ The clash that emerged between old trade unionists' and young New Dealers' views of economic freedom reveals competing conceptions of early-twentieth-century reform rights-one formal and antistatist, the other pragmatist and "progressive"; one inherited, the other emergent in reform discourse.

\section{Id. at 754 .}

80. Id.

81. Id.

82. Franklin D. Roosevelt, Acceptance of the Renomination for the Presidency, Philadelphia, Pa. (June 27, 1936), in 5 Franklin D. Roosevelt, The Public PaPers AND AdDresses of Franklin D. RoOSEVElt 230, 233-34 (Samuel I. Rosenman ed., 1938).

83. This is the chapter in the history of New Deal rights creation that James Gray Pope brilliantly explores. See generally Pope, The Thirteenth Amendment, supra note 17. 
Unlike Roosevelt, Wagner and other progressive Democrats and Republicans in Congress long had championed labor's rights to strike, organize, and bargain collectively. Since the 1900s, they had supported the labor movement's struggles against private and statesponsored repression of strikes and organizing and, like organized labor, they framed their case for legislative repeal of judge-made law largely in constitutional terms. While courts repeatedly rejected these constitutional claims, progressives in Congress agreed that workers' industrial rights were bottomed on the First, Thirteenth, and Fourteenth Amendments. ${ }^{84}$ The main target of these constitutional struggles was the labor injunction, which appeared in the Gilded Age as the nation's courts vastly enlarged their role in regulating and policing industrial conflict. " America's distinctive contribution in the application of law to industrial strife," ${ }^{, 6}$ the labor injunction was bound up with the ruthless use of public and private violence to suppress organizing, strikes, and boycotts.

1. “Government by Injunction” and Labor's Constitution. By a conservative reckoning, at least 4300 injunctions were issued between 1880 and $1930 .^{87}$ These enjoined only a small fraction of the total number of strikes for most of those five decades, although by the 1920 s the fraction would increase to twenty-five percent. ${ }^{88}$ Every injunction represented a new, particularized set of legal commands for strikers that supervened the policies and discretion of local officials. ${ }^{89}$ Neither direct legal violence nor the countless incidents of federal courts trumping elected state and local authorities was the most serious dimension of the injunction problem, however. Worst was the indirect, cultural force exerted by judge-made labor law. That law had infused and "“disfigured," in Sam Gompers's words, the very language with which " "newspapers... [and] the common people" perceived and

84. William E. Forbath, LAW AND THE SHAPING OF THE AMERICAN LABOR MOVEMENT 160 (1991); Forbath, supra note 6, at 60.

85. FORBATH, supra note 84 , at 59.

86. Felix Frankfurter \& Nathan Greene, The Labor InJunCtion 53 (1930).

87. FORBATH, supra note 84 , at $61,193-98$.

88. Id. The proportion of large secondary actions (such as sympathy strikes or refusals to carry or work on "unfair goods") that were enjoined was substantial throughout these decades. By the 1920s, forty-six percent of sympathy strikes and boycotts were greeted by injunctions. Id. at 61-62. Injunctions also figured in virtually every railroad strike; in most major organizing and recognition strikes and anti-union-open-shop lockouts; and in a small but still significant and growing portion of ordinary primary strikes. Id. at 62.

89. Id. at 103 . 
talked about the labor movement..$^{90}$ It enabled hostile employers and public officials to depict peaceful protest and mutual aid as the acts of outlaws. Vastly more numerous than strikes broken by decree were those suppressed by hostile officials or private police relying on the illegality of picketing, boycotts, organizing, and union shop strikes. ${ }^{91}$

Abolishing the judge-made restrictions on collective action proved to be the chief political goal of the American Federation of Labor (AFL) from the 1890s until the New Deal. ${ }^{92}$ This struggle prompted the generations of labor leaders and rank-and-file activists whose careers unfolded during those decades to steep themselves in constitutional law, common law doctrine, and equity jurisprudence. Their protests began to rely on a labor variant of liberty of contract. Alongside this liberal common law-based critique of judicial repression appeared a new rendering of another vein of constitutional tradition, the Thirteenth Amendment and the Antislavery Constitution.

By the first decade of the new century, the AFL's national leadership had abandoned the ambitions of their Gilded Age predecessors. They no longer proposed to use legislation to change the face of the nation's industries and political economy. "“[L]abor," Gompers proclaimed, " "does not depend on legislation. It asks ... no favors from the State. It wants to be let alone and to be allowed to exercise its rights ....",93

Scrutinizing the common law that cast them into semi-outlawry, AFL leaders developed insights akin to those of the era's greatest critic of legal orthodoxy. Like Justice Holmes of the Supreme Judicial Court of Massachusetts, trade unionists would compare the doctrine of competitive freedom in cases between business firms with the doctrines of security of property interests and of contractual expectations that underpinned labor injunctions. These property- and contract-based doctrines often failed in business-against-business cases, yet the same doctrines always prevailed in suits brought by businesses against unions. Thus, when commenting on antiboycott decrees, the AFL would point out that had the action taken by the labor organization instead been taken by manufacturers, it "might have been fairly considered a legitimate battle of trade with which a court of equity should not have inter-

90. Id. at 125 (quoting Samuel Gompers).

91. Id. at 126 .

92. Id. at 128 .

93. Id. at 130 n.8 (quoting Samuel Gompers). 
fered," but courts granted "a certain class immunity against the ordinary vicissitudes and hazards of business." $"$

Labor's freedom to strike and boycott, AFL spokesmen insisted, was secured by the same legal principles that guaranteed employers' market freedom. "The whole gospel" of the labor movement, Gompers proclaimed, "is summed up in one phrase... freedom of contract-organized labor not only accepts, but insists upon, equality of rights and of freedom." ${ }^{95}$

Justice Holmes's famous 1894 essay, Privilege, Malice, and Intent ${ }^{96}$ and his dissent in Vegelahn v. Guntner ${ }^{97}$ addressed the same contradiction. The common law rules that guarded employers' businesses against union interference-rules based on security of property and contractual expectations-clashed with the common law principles of competitive freedom. ${ }^{98}$ If relied on in labor cases as they were elsewhere, these contrary doctrines could warrant denying antistrike decrees in cases where they were routinely granted.

The lesson for Holmes was that recourse to these principles could not decide concrete cases. One had to make a policy judgment, and Justice Holmes, for one, favored extending to labor organizations much the same freedom of action that businesses enjoyed. ${ }^{99}$ But labor's early-twentieth-century constitutional tribunes did not share Holmes's legal pragmatism. Rather, like the Lochner Court's classical liberals, they thought general principles usually could decide concrete cases; for them, every antistrike decree trenched on labor's constitutional rights under the First, Thirteenth, and Fourteenth Amendments. The thoroughly modern, pragmatic, policy-minded judge or lawmaker had no more constitutional warrant to restrict labor's freedom of action than the most hidebound Lochnerite. The Lochnerite's

94. Limiting Federal Injunctions: Hearings on H.R. 23,635 Before a Subcomm. of the S. Comm. on the Judiciary, 62d Cong. 394-95 (1912) (statement of T.C. Spelling), quoted in FORBATH, supra note 84, at 132 n.12. For a more detailed account of how trade unionists embraced and wielded this common law competitive-freedom rights rhetoric, see generally FORBATH, supra note 84, at 128-66.

95. FORBATH, supra note 84, at 131 n.9 (quoting Samuel Gompers).

96. 8 HARV. L. REV. 1 (1894).

97. 44 N.E. 1077, 1080-81 (Mass. 1896) (Holmes, J., dissenting).

98. See id. (exploring why free competition among businesses is encouraged, when free competition between employers and employees, via trade unions, is not).

99. See id. at 108 :

If it be true that workingmen may combine with a view, among other things, to getting as much as they can for their labor, just as capital may combine with a view to getting the greatest possible return, it must be true that, when combined, they have the same liberty that combined capital has .... 
sole error lay in his neglect of relevant constitutional commands and his obedience to counterfeit ones, by slighting "human rights" in favor of "property rights."

This difference between classical and pragmatist-minded reform came home to roost in the disputes between the old trade unionists and the progressive and New Deal lawyers over the drafting of the NorrisLaGuardia and Wagner Acts. The lawyers were not wrong in seeing the jurisprudence they hoped to topple reflected in the old labor constitutional outlook.

Labor's outlook had other legal-constitutional sources as well. Not liberty of contract alone, but also the legacy of the antislavery movement and the Thirteenth Amendment lent constitutional heft to labor's blows against its court-forged manacles. According to this legacy, the dignity and independence of free labor were inscribed in the Constitution. It smacked of slavery, trade unionists complained, or of feudalism, at best, when courts routinely held that employers had a property right in their workers' returning each day to toil in the employers' plants, or a property right in their workers' non-union status, or a property right in their authority to run the plant without contending with workers seeking to negotiate over union work rules. ${ }^{100}$

Such holdings were essential because equity required an injury to property for an injunction to issue. Gilded Age equity doctrine still tended to view property as dominion over things, and equity judges in the early 1880 s occasionally denied antistrike and boycott decrees on the grounds that the unions' actions constituted no invasion of "any clear right of property."

100. See FORBATH, supra note 84, at 85 (describing how courts expanded the scope of the definition of property to include the labor of another by reviving the old common law conception of the master-servant relationship).

101. Johnston Harvester Co. v. Meinhardt, 31 N.Y. Sup. Ct. 489, 489 (1881), aff'g 9 Abb. N. Cas. 393 (N.Y. 1880), quoted in FORBATH, supra note 84, at 81. Until the late 1890s, equity courts generally deemed as "things," and therefore protected by injunction, a few intangible rights, most notably those inhering in state-granted franchises. See, e.g., Croton Tpk. Rd. Co. v. Ryder, 1 Johns. Ch. 611, 615 (N.Y. Ch. 1815) ("It is settled that an injunction is the proper remedy to secure to a party the enjoyment of a statute privilege [i.e., a state-granted franchise], of which he is in the actual possession, and when his legal title is not put in doubt."); HENRY L. MCClintock, HANDBOOK ON THE PRINCIPLES OF EQUiTy § 150 (2d ed. 1948) ("An exclusive franchise granted to a person to conduct a particular business or render a particular service confers a property right which may be protected by an injunction ...."). Still, equity courts generally distinguished "property rights" from "personal and civil rights," deeming the latter to be outside the fold of equity's power to grant injunctions. See, e.g., THOMAS C. SPELLING \& JAMES HAMILTON LEWIS, A TREATISE ON THE LAW GOVERNING INJUNCTIONS § 7 (1926):

As is generally known, equitable jurisdiction was originally founded on the protection of property and property rights; but, however[] much the original basis has been ad- 
more general vein of recent doctrinal development, what legal historians have dubbed the late nineteenth century's "dephysicalization" of property - the expansion of intangible property rights such as business goodwill and trade secrets. ${ }^{102}$

The view that employers had a property interest in their workers' labor had ancient as well as modern sources. For centuries the common law had recognized the property interests of masters in their servants' obedient toil, and some of these legal claims persisted into the nineteenth century. ${ }^{103}$ For another century beyond that, the view that an employer had a property interest in his workers continued to inform the old common law action for enticing away another's servants. ${ }^{104}$ From the start, the enticement tort was wielded against unions, but its use was perfected in the 1910s and 1920s, when millions of American workers were made to sign "yellow dog" contracts, promising not to affiliate with any union or labor organization, and employers routinely were granted decrees against union organizing, on the ground that the unions' recruitment efforts, however peaceful, were a species of the old common law wrong of enticement and infringed the employer's property interest in the contracted-for, non-union status of their workers. ${ }^{105}$

\footnotetext{
hered to in theory, the jurisdiction unquestionably has been within recent decades considerably expanded .... But these instances constitute mere exceptions to the general rule of adherence to the protection of property and property rights as a basis.

102. See Morton J. Horwitz, The Transformation of AmericAn LAw, 1870-1960, at 31 (1992):

As the spirit of economic development began to take hold of American society in the early years of the nineteenth century ... the idea of property underwent a fundamental transformation-from a static agrarian conception entitling an owner to undisturbed enjoyment, to a dynamic, instrumental, and more abstract view of property that emphasized the newly paramount virtues of productive use and development.
}

Kenneth J. Vandevelde, The New Property of the Nineteenth Century: The Development of the Modern Concept of Property, 29 BUFF. L. REV. 325, 333-40 (1980) (arguing that after the Blackstone era, courts began to dephysicalize property by defining property in terms of the right to value rather than the right to some tangible object, and created nonphysical forms of property).

103. Robert J. STEINFELd, THE INVENTION OF FreE LABOR: THE EMPLOYMENT RELATION IN ENGLiSH AND AMERICAN LAW AND CUlTure, 1350-1870, at 135-36, 174-75 (1991).

104. See Karen OrRen, Belated FEudalism: LABor, the LAw, AND Liberal DEVELOPMENT IN THE UNITED STATES 40 (1991) ("Along with other common-law writs, the action of enticement would carry on long after the old labor statutes had become a dead letter, being pressed into active service in the industrial battles in the late nineteenth and twentieth centuries.").

105. FORBATH, supra note 84, at 85-86, 116-17; EDWARD A. PURCELL, JR., BRANDEIS AND the Progressive Constitution: ERIE, the Judicial Power, AND the Politics of THE FEDERAL COURTS IN TWENTIETH-CENTURY AMERICA 75-77 (2000) (describing the role of federal equity in enforcing yellow-dog contracts). 
This rash of decisions and doctrinal developments regarding employers" "property" inspired the anti-injunction movement's slogan "No Property Rights in Man!" The decisions' "feudal," "slavish" tenor, combined with their frequent practical effect of forcing workers to return to work, prompted leaders like Gompers to denounce the labor injunction as a judicial reenactment of slavery. ${ }^{106}$ It was not Gompers, however, but Victor Olander, president of the powerful Illinois Federation of Labor, and Andrew Furuseth, head of the International Seamen's Union of America and the AFL's chief lobbyist, who most carefully fashioned the links between the Thirteenth Amendment and labor's rights to organize and to strike. The Thirteenth Amendment, they would say, was "“a glorious labor amendment"”; ${ }^{107}$ it stood for the "fundamental principle of American law... that there shall be no property rights in man.",108

Labor's theory that either the Thirteenth or the Fourteenth Amendment safeguarded workers' collective action found scant favor in the courts but ample support in the legislatures. In all, state and federal lawmakers enacted roughly forty-five anti-injunction statutes in the decades before the New Deal. ${ }^{109}$ From the 1890s through the 1920s, courts struck down these laws expanding the freedom to associate and act in concert beyond court-imposed boundaries, or else they construed them in the manner of the Supreme Court, with the labor provisions of the Clayton Antitrust Act of $1914,{ }^{110}$ as leaving the common law of the labor injunction unchanged. ${ }^{111}$

106. Samuel Gompers, Government by Injunction, 4 AM. FEDERATIONIST 82, 82 (1897).

107. Victor Olander, The Constitution, the Free Man, and the Slave, Radio Talk (May 30, 1925), cited in FORBATH, supra note 84, at 137.

108. FORBATH, supra note 84, at 137 n.34 (quoting Andrew Furuseth). The "vital case," explained Olander, was Bailey v. Alabama, 219 U.S. 219 (1911), which struck down an Alabama debt peonage statute providing criminal sanctions for breach of a labor contract paid in advance. $I d$. at 227-45. "What the State may not do directly [apply its coercive arm to hold laborers to their toil]," the Bailey Court reasoned, "it may not do indirectly." Id. at 244. For detailed accounts of how Olander and other labor jurists deployed the Court's condemnation of indirect state compulsion to criticize the law of the labor injunction, see FORBATH, supra note 84, at 135-40; Pope, The Thirteenth Amendment, supra note 17 (manuscript at 115-16).

109. Many of these statutes protected peaceful picketing; others outlawed yellow-dog contracts or exempted labor boycotts from antitrust laws; still others legislated an even broader freedom for workers' collective action. FORBATH, supra note 84, at 151.

110. Antitrust Act of 1914, Pub. L. No. 63-212, 38 Stat. 730 (codified as amended at 15 U.S.C. $\S \S 12-36$ (1994)).

111. See Duplex Printing Press Co. v. Deering, 254 U.S. 443, 478 (1920):

Reaching the conclusion, as we do, that complainant has a clear right to an injunction under the Sherman Act as amended by the Clayton Act, it becomes unnecessary to consider whether a like result would follow under the common law or local statutes; there being no suggestion that relief thereunder could be broader than that to which 
This wealth of experience with anti-injunction laws in judicial hands was one reason it seemed treacherous to labor law reformers like Felix Frankfurter to ask Congress to rely on the Constitution's libertyand rights-protecting amendments as a basis for enlarging organized labor's liberty. Faced with mounting criticism of "government by injunction," the Court might just accede to some diminution of federal equity jurisdiction or to some enlargement of Congress's authority to regulate and set the bounds of industrial protest. These alternatives seemed less threatening and provocative than constitutionalizing labor's collectivist version of laissez-faire, which would require the Court to agree that the Constitution immunized the very activities-picketing, boycotting, joining unions free from reprisals- the Court had found to trench on constitutional liberty.

2. The Norris-LaGuardia Act and the Clash of Progressive and Formalist Styles of Law Reform and Constitutional Interpretation. Immunity for picketing, boycotting, and union membership was exactly what the AFL's Andrew Furuseth and other AFL spokesmen asked from Congress, as progressive Republican George Norris, chairman of the Senate Judiciary Committee, commenced a new round of hearings on the labor injunction in the winter of $1928 .^{112}$ Drafted by Furuseth, the initial bill before Norris's committee was not lengthy, and, like previous bills authored by Furuseth over the decades, it turned on the definition of property. It provided that "for the purpose of determining" equity courts' jurisdiction to protect property, "nothing shall be held to be property unless it is tangible and transferable." 113 By cutting "property" back to its Blackstonian borders, Furuseth hoped practically to abolish the labor injunction by barring equity courts from finding a property interest in any of the social-economic relationships affected by union activity, be it the employer's expectancy that "his" workers would return each day to his plant or the same employer's capacity to produce goods by using their toil. At the same time, Furuseth's bill made a symbolic statement about property versus personhood in the social relations of industrial

complainant is entitled under the acts of Congress.

112. See Limiting Scope of Injunctions in Labor Disputes: Hearings Before the Subcomm. of the Comm. on the Judiciary, 70th Cong. 19 (1928) [hereinafter Limiting Scope] (statement of Andrew Furuseth) (urging Congress to return to a Blackstonian definition of property), cited in FORBATH, supra note 84, at 160 n.131.

113. IRVIng Bernstein, THe Lean Years: A History of the AMERICAN Worker 1920-1933, at 395 (1960) (quoting S. 1482, 69th Cong. (1927)). 
work. A contemporary property theorist would say the bill aimed to declare certain limits on the alienability and commodification of labor. "Now we ... come to you," Furuseth declared at the hearings' opening, "to ask you to determine what is property, what constitutes property. That is the pith and essence of the question."114 By treating people as a form of property, the labor injunction broke the promise of the Thirteenth Amendment. "If [the courts] go on making human relations into property relations," Furuseth argued, "the thirteenth amendment to the Constitution will be evaded, circumvented, and dead." ${ }^{115}$

As the hearings unfolded, the AFL bill was assailed not only by employers' representatives but by union-side labor lawyers and by legal academics and progressives. The former contended that Furuseth's sweeping language would surely be either struck down or construed in a way that failed to prevent courts from finding a basis on which to issue antistrike decrees. The progressive legal reformers and academics objected that Furuseth's bill swept too broadly, eliminating entirely useful equitable protection for all kinds of intangible property rights including patents and copyrights. ${ }^{116}$ For the legal academics, Furuseth's attempt to narrow the law's definition of property back to eighteenth-century terms was absurd and anachronistic. Felix Frankfurter was the most prominent academic critic of the labor injunction; Frankfurter patronizingly put Furuseth's efforts down as a "self-taught seaman['s] . . attempt to throw out the baby with the bath."117

Senator Norris enlisted Frankfurter and a number of other progressive legal reformers to draft a substitute bill. Theirs made no mention of "property," but was a thorough and well-crafted set of hedges against the labor injunction, imposing detailed limits on the jurisdiction of federal courts to issue injunctions in labor disputes and declaring

114. Limiting Scope, supra note 112, at 24.

115. Id. at 148. Whether forbidding speech, assembly, or quitting work in concert, labor injunctions, so Furuseth contended, necessarily rested on the notion that the employer owned some kind of property interest in workers' conduct. Senator Shipstead, who had introduced the bill on the AFL's behalf, echoed this perspective when he concluded that the month-long hearings had revealed a distinct conflict between the Fifth and Fourteenth Amendments on one side and the First and Thirteenth Amendments on the other. FoRBATH, supra note 84, at 160. So too would Senator Norris in telling the Senate that the labor injunctions' "effect has often been involuntary servitude on the part of those who must toil in order that they and their families may live." 75 CONG. REC. 4502 (1932) (statement of Sen. Norris).

116. See Frankfurter \& GreEne, supra note 86, at 207-08 (arguing that Furuseth's bill "condemns many well settled and benificent [sic] exercises of equitable jurisdiction that do not touch even remotely the interests of labor").

117. Id. at 207. 
yellow-dog contracts void and unenforceable in federal courts as against public policy. ${ }^{118}$ As a statement of "the public policy of the United States," Frankfurter's substitute bill began by embracing Furuseth and the AFL's general theory of labor's liberty. ${ }^{119}$ But making national "policy" out of the freedom to associate, organize, and engage in concerted action was not enough for Furuseth. With labor and labor's friends divided, the substitute bill died in committee. ${ }^{120}$

Furuseth's response to the "baby with the bath" criticism was a new bill, which adopted the progressives' tactic of limiting federal jurisdiction to issue labor injunctions, but did so by decreeing the existence of affirmative labor rights under the Thirteenth Amendment. ${ }^{121}$ The bill then withdrew federal jurisdiction to interfere with the exercise of those rights. Section 2 of the Thirteenth Amendment, after all, conferred on Congress "a broad discretion in determining the exact scope of necessary legislation" including "a proper discretion as to the ultimate meaning and scope of the term "involuntary servitude.", 22

Once more, Frankfurter, the other labor lawyers, and progressive law reformers in Senator Norris's brain trust demurred; the notion of relying on the Thirteenth Amendment to halt "government by injunction" was to Frankfurter "of a simplicity that borders on the fantastic." ${ }^{\prime 23}$ Norris decided to stick with the bill that Frankfurter and com-

118. Id. at 279-88 (reprinting the text of the substitute bill).

119. The bill declared that the

individual unorganized worker is commonly helpless to exercise actual liberty of contract and to protect his freedom of labor [in his dealings with property owners organized in corporations and other ownership associations] wherefore it is necessary that he have full freedom of association, self-organization, and designation of representatives of his own choosing to negotiate the terms and conditions of his employment, and that he shall be free from the interference, restraint, or coercion of employers of labor, or their agents in [his] self-organization or in other concerted activities for the purpose of collective bargaining or other mutual aid or protection ....

Id. at $280-81$.

120. Cf. Felix Frankfurter \& Nathan Greene, Congressional Power over the Labor Injunction, 31 COLUM. L. REV. 385, 388 (1931) (predicting that the bill would die in committee).

121. Thus, Furuseth's new bill provided that

"[E]very human being has under the thirteenth amendment ... an inalienable right to the disposal of his labor free from interference, restraint or coercion by or in behalf of employers of labor ... the right to associate with other human beings for the protection and advancement of their common interests as workers ... to negotiate through representatives of their own choosing ... and to take concerted action for their own protection in labor disputes."

Pope, The Thirteenth Amendment, supra note 17 (manuscript at 276) (quoting Furuseth's new bill).

122. Id.

123. Id. (manuscript at $86-87$ ). 
pany had drafted, and in January 1932 the Norris-LaGuardia AntiInjunction $\mathrm{Act}^{124}$ sailed through Congress. The House bill passed by a vote of 362-14; the Senate bill by a vote of $75-5 .{ }^{125}$ The early 1930 s had seen a crisis of both business and Republican party legitimacy, and this combined with the more specific disrepute of the old labor law regime to produce the remarkably broad support the Norris and LaGuardia bills enjoyed.

Legal reformers like Frankfurter and Brandeis and progressive lawmakers like Norris, LaGuardia, and Wagner favored a broad freedom of collective action for organized labor. By repealing repressive judge-made law and instituting a national legislative policy supporting that broad freedom (to engage, for example, in many forms of secondary action), they aimed to undergird unions with substantial economic power. Only then would employers assent to collective bargaining. They were leery, however, of making that freedom categorical. Differing widely among themselves, they all envisioned some form of public, legal accountability on labor's part for unwarranted forms of economic injury. What kinds of injuries or strike or boycott objectives were unwarrantable was not a determination they thought could be made once and for all at a high level of generality. If it was blind formalism when courts treated the individual worker as the legal equal of the corporate employer, it also was blind formalism to ignore the differences between individual and collective marketplace action on the part of workers. Yet, often trade unionists' invocations of the Thirteenth Amendment seemed to do just that, prompting Frankfurter to complain that Furuseth's reasoning blithely assumed that "the criteria of law and of policy regarding the actions of individuals [were] coextensive with the criteria applicable to the actions by men in concert."

These progressives did not dispute that constitutional principles were at stake. Rather, for them, labor's collective freedoms were at once a matter of right, the repression of which under the present legal regime denied workers the democratic voice and dignity in work life to which all citizens were entitled, and a matter of policy, insofar as these collective freedoms, while broad, were necessarily matters of

124. Norris-LaGuardia Act, Pub. L. No. 72-65, 47 Stat. 70 (1932) (codified as amended at 29 U.S.C. $\S \S 101-15(1994))$.

125. I recount these developments in FORBATH, supra note 84, at 162-64.

126. Letter from Felix Frankfurter to Senator Shipstead, Mar. 23, 1931, Norris Papers, Box 285, quoted in Pope, The Thirteenth Amendment, supra note 17 (manuscript at 87 n.183). 
degree and context-dependent. Deciding their metes and bounds involved complex factual considerations and considered political judgments; this pointed, in the progressives' minds, away from courts and toward legislative and administrative determinations. ${ }^{127}$

The progressives did not defend this allocation of interpretive authority and policymaking responsibility on functional grounds alone. They also had prudential and principled reasons. Prudentially, it seemed wise to shift the interpretation and enforcement of labor rights as far as possible from judicial hands. The courts had their own longstanding conceptions of labor's constitutional freedom and could be expected to infuse these old conceptions into any new constitutional discourse framed around labor's liberty. As a matter of principle, in a democracy freed from judicial fiat and capitalist tyranny, progressives thought, trade unionists really ought to be obliged to vindicate their broad reading of labor's constitutional liberty in the arena of public political deliberation and decisionmaking.

So, the progressives had weightier reasons for resisting the courtbound constitutionalization of labor's new rights than simply expanding the power of experts, policymakers, and lawyers attached to the emergent administrative state. When they argued that labor's rights be viewed as "policy" rather than fundamental law, it was the fundamentalism of the laissez-faire Constitution and judicial supremacy in expounding the Constitution they spurned. They plainly agreed that constitutional personhood and citizenship were at stake in the conditions and commodification of labor.

The progressives' views were not unanswerable, but Furuseth, Gompers, and their cohorts did not answer them. They were caught in the coils of their own variant of the rigid classical liberalism of their judicial foes. The courts had great trust in themselves and little in the other branches of government; the AFL leaders distrusted the state in toto. By their lights, the only valid limits on strikes and boycotts were ones that unions voluntarily imposed on themselves. Yet these national craft union leaders were conversant with power; they did not need to read Robert Hale to know that even the peaceable strike or boycott was a species of "coercion" as well as an act of solidarity and a form of social and political expression. ${ }^{128}$ This was what Frankfurter had in mind when

127. See Daniel Ernst, The Yellow Dog Contract and Liberal Reform, 1917-1932, 30 LAB. HIST. 251, 264-74 (1989) (discussing the fact- and policy-based approach of the progressive labor law reformers).

128. See Robert Hale, Coercion and Distribution in a Supposedly Non-Coercive State, 38 POL. SCI. Q. 470, 474 (1923) (arguing that workers as well as employers wield economic coer- 
he derided the AFL's reliance on the Thirteenth Amendment as "silly" and simplistic ${ }^{129}$ for conflating individual and collective freedom from legal constraint. Gompers and the other AFL advocates simply underscored the "helplessness" of the individual worker and the inveterate hostility of the courts toward workers' collective action, as though these facts, combined with the Thirteenth Amendment, compelled collectivizing the individual's freedom and applying it categorically to union action. Frankfurter's views may have been profoundly cautious, arrogant, and elitist, but he was not wrong here. The AFL leaders' decades-old arguments were wooden, and they rested on a policy premise - that the nation had to trust trade unions to police themselves-few middle-class Americans, including middle-class progressives, could abide. Propounding a Thirteenth Amendment right to strike demanded a substantive defense of a vast freedom of collective economic action as well as a more persuasive conception of organized labor's public accountability. ${ }^{130}$

Even so, generations of organized workers, as well as women and racial minorities, might have been better served had Furuseth's views and hopes prevailed. Had the progressive attorneys viewed the AFL's constitutional ideals more sympathetically, they could have recast them in less absolutist terms. And if Congress had agreed to rest workers' new statutory freedom on the "glorious labor amendment," it would have forced a showdown with the courts over the meaning of the Thirteenth Amendment and labor's constitutional freedoms. Finally, had the courts assented to labor's Constitution, they would have set in motion an expansion of Americans' rights based on the rights-affirming provisions of the Constitution. Given the legal and political obstacles arrayed against that outcome in the late 1920s and early 1930s, it is hard to imagine success, no matter the arguments put forward. A few years later, however, when the Wagner Act was framed and defended, the Court and the old Constitution were on the ropes. Organized labor was resurgent, millions of workers were flocking into a new and militant industrial union movement and demanding a new place for workers in the

cion). On Hale's role in the progressive attack on the injunction and judge-made labor law, see Barbara Fried, The Progressive Assault on Laissez Faire: Robert Hale and the FIRST LAW AND ECONOMICS MOVEMENT 8-9 (1998).

129. Pope, The Thirteenth Amendment, supra note 17 (manuscript at 85-87) (quoting Frankfurter)

130. Compare Pope's own supple and policy-minded case for a constitutional right to strike in James Gray Pope, Labor and the Constitution: From Abolition to Deindustrialization, 65 TEX. L. REV. 1071 (1987). 
nation's legal and constitutional order. ${ }^{131}$ New Dealers in Congress endorsed their demands as they passed Senator Wagner's Act, and so did an enormously popular president. It was a political-constitutional climacteric. In the heat of this contest over constitutional basics, what had been fixed and solid was becoming fluid and changeable. Was not this the moment for grounding labor's exiled rights on a new reading of the Civil War Amendments?

3. The Wagner Act and the Political Constitution. Historians have amply shown the centrality of citizenship rights in the outlook and arguments of the Wagner Act's proponents. ${ }^{132}$ The Senate report on Wagner's labor dispute bill described employers' common law authority over workers and workplace as a constitutional as well as a social and economic blight. That authority deprived workers of rights at work that were inherent in citizenship: "to be free to form or join organizations, to designate representatives, and to engage in concerted activities." ${ }^{133}$ As Pope shows, Wagner was clear that committing the national government to safeguarding these rights was the Act's primary goal; its other goals of fostering industrial peace and increasing workers' purchasing power were secondary. ${ }^{134}$

Why then, asks Pope, when Wagner so earnestly embraced labor's constitutional outlook, did he spurn the labor movement's project of enshrining collective labor rights in constitutional law? ${ }^{135}$ Part of the answer is that by 1935 this was no longer the labor movement's project. Only a handful of older AFL leaders of Gompers's generation still cared about resting labor law reforms on the Thirteenth Amendment, and, as Pope notes, most of them "were mired in a conservative voluntarism that made them suspicious of the Wagner Act." ${ }^{136}$ These oldfashioned craft unionists feared any dependence on the state for protection and any reauthorization of the courts to issue injunctions in labor disputes, even to enforce the orders of a labor board designed to safeguard unionization and collective bargaining. ${ }^{137}$ Thus, most of them op-

131. See infra notes $153-59$ and accompanying text.

132. See Forbath, supra note 6, at 60-61 \& n.265 (detailing the citizenship rights-based arguments for the Wagner Act and citing sources); Pope, The Thirteenth Amendment, supra note 17 (manuscript at 102-12) (describing centrality of citizenship rights-based arguments as compared to arguments based on facilitating commerce).

133. S. REP. No. 79-1184, at 4 (1934), quoted in Forbath, supra note 6, at 61.

134. Pope, The Thirteenth Amendment, supra note 17 (manuscript at 125).

135. Id. (manuscript at 260).

136. Id. (manuscript at 115).

137. Id. 
posed the law, which hardly commended their constitutional views to the Act's sponsors. ${ }^{138}$

The labor movement's progressives, socialists, and industrial unionists, by contrast, had long defended the positive uses of state power on labor's behalf-to enact social insurance and state-enforced labor standards and to lend affirmative protection to union organizing and collective action. ${ }^{139}$ Not coincidentally, these tended to be the leaders, like Sidney Hillman of the Amalgamated Clothing Workers, who sought to organize the unskilled, new immigrant workers excluded by the AFL's craft unions; like Hillman, they moved from the margins to the center precincts of labor politics during the New Deal. ${ }^{140}$

There was prescience in the outlook of the old voluntarists, but it meant that only Furuseth combined support for the Wagner Act with a conviction that it must rest on the "glorious labor amendment," and not the Commerce Clause. Furuseth had a prophetic insight about the longterm value of forcing a confrontation with the courts over the meaning of labor's constitutional liberty, but his arguments fell on deaf ears.

Progressives like Wagner and Norris hewed to a tradition of constitutional thought that envisioned lawmakers themselves engaged in genuine tasks of constitutional interpretation and remediation. Theirs was a political, not a judicial, Constitution; the courts, after all, had done precious little on behalf of reform constituencies. Although historians have pointed out the Lochner Constitution's deep roots in Jacksonian laissez-faire and Lincolnian Free Labor thought and jurisprudence, ${ }^{141}$ to

138. Id.

139. See Steve Fraser, Dress Rehearsal for the New Deal, in Working-Class AMERICA 212, 220-21 (Michael H. Frisch \& Daniel J. Walkowitz eds., 1983) [hereinafter Fraser, Dress Rehearsal] (describing Hillman's garment workers union's experiments with public and governmental support for unionization and collective bargaining as a "dress rehearsal" for the New Deal). See generally STEVE FrASER, LABOR WiLl RUle: Sidney Hillman AND THE RISE Of AMERICAN LABOR (1991) [hereinafter FRASER, LABOR] (detailing progressive and socialist unionists' affirmative views of uses of state power).

140. See generally FRASER, LABOR, supra note 139 (describing the ascent of Hillman and other progressive unionists to positions of national leadership in the labor movement and national government during the New Deal); Fraser, Dress Rehearsal, supra note 139, at 221 (explaining that progressive industrial unionists like Hillman had become acquainted during World War I and after, at state and local levels, with the "mechanisms of policy-making and the institutional interior of a state apparatus").

141. See generally Howard Gilman, The Constitution Besieged: The Rise AND DEMISE OF LOCHNER ERA POlice POWERs JuRISPRUdenCE 33 (1993) (arguing that laissezfaire was transformed into constitutional ideology and jurisprudence during the Jacksonian era); William E. Forbath, Ambiguities of Free Labor: Labor and Law in the Gilded Age, 1985 WIS. L. REV. 767 (maintaining that the laissez-faire constitutionalism of the late nineteenth century was crafted by jurists imbued with Jacksonian or Lincolnian values that they transposed, onesidedly, to industrial life); Michael Les Benedict, Laissez-Faire and Liberty: A Re-Evaluation of 
contemporary reformers, the Lochner Court and its Constitution were the safeguards of the constitutional rights of large corporations, industrial raptors preying on "the People." ${ }^{142}$ From the 1880s until the late 1930s, it was rare indeed that a reformer's invocation of the Constitution's promise of equal rights or its guarantees of civil and political liberties would be addressed to the courts. Reformers brought their constitutional grievances and aspirations to the legislatures. Specifically, the social citizenship tradition held that lawmakers, and not the courts, were the appropriate interpreters and guardians of an important subset of fundamental rights, ${ }^{143}$ including the rights to social provision, decent labor standards, and decent work. It was patent to generations of populists and progressives that the courts not only would not, but also could not and should not translate the general rights-declaring provisions of the Reconstruction Amendments into specific guarantees of social and economic rights in industrial America. ${ }^{14}$ That required redistributive legislation and administrative machinery and a broad national political will to support them. The only important contribution the courts could make to this essentially political and legislative task was to allow the process to go forward. Once one conceived of labor's collective freedoms in terms of affirmative rights to government protection, they too fitted this mold.

Given that the Court had colonized the Reconstruction Amendments' guarantees, Furuseth's proposed confrontation with the Court's constructions of economic liberty under the Reconstruction Amendments must have seemed a folly to progressives, heightening the chances of invalidation on the extraordinarily slender hope that the Court would make labor's Constitution its own. ${ }^{145}$ With the exception of Furuseth and the other conservative voluntarists, who opposed the very principle of affirmative government protection of labor rights, labor's councils agreed with the tack chosen by Wagner's draftsmen. Like the

the Meaning and Origins of Laissez-Faire Constitutionalism, 3 LAW \& HIST. REV. 293 (1985) (tracing the antebellum and Civil War-era antecedents of laissez-faire constitutionalism).

142. See Forbath, supra note 6, at 5 (noting that the Lochner Court found an "antidistributive norm" in the Constitution and that the reformers found a "distributive one").

143. Id. at 23-61.

144. Id.

145. Remember, the Wagner Act left unaddressed the extent to which its protection of concerted activity altered other federal legal restraints on strikes and boycotts, like the Sherman Act. Its drafters insisted that it did not affect state-law limitations. Recognizing a Thirteenth or Fourteenth Amendment basis for the freedom of collective action, however, arguably would trump both these categories of legal restraints. 
congressional progressives, theirs was a political Constitution and a legislative vision of fundamental rights. ${ }^{146}$

In the courts, then, progressive government and union-side labor attorneys defended the Wagner Act on Commerce Clause grounds; in Congress and in public discourse, progressive lawmakers and labor leaders defended it on grounds of citizen-workers' constitutional rights and liberties. And in both arenas, the Act's defenders prevailed.

Norris-LaGuardia had done no more than prevent judicial repression of union workers' exiled freedoms; it did nothing to protect them against employer interference and coercion. Only with the Wagner Act was the employer's common law authority over workers and workplace largely torn away; employers were forbidden from interfering with workers' rights to organize, act in concert, and, through union cards or government-supervised elections, select "representatives of their own choosing" with whom employers were obliged to deal.

The Act's passage prompted renewed organizing campaigns by the Congress of Industrial Organizations (CIO) and massive defiance by employers. ${ }^{147}$ Organizers and activists continued to be fired, beaten, and blacklisted, and where new unions sprang up, employers continued to refuse recognition. They defended their defiance of the Act in the name of contract, property, and states' rights, and their claims were uniformly upheld by the lower courts, which enjoined enforcement actions by the new National Labor Relations Board

146. There may be something close to a proof text here. If enshrining collective labor rights in constitutional law was indeed the project of the era's labor movement, then one would think that any constitutional amendment that unions would sponsor to authorize a new labor law regime would be framed in the language of rights and would seek to inscribe collective labor rights in the Constitution. Yet, the amendments put forward by union delegates at the American Federation of Labor conventions did not take that form, nor did the amendments championed by labor's friends in Congress. Most prominent was the Workers' Rights Amendment, which, as Pope notes, was submitted and supported by industrial union delegates. Pope, The Thirteenth Amendment, supra note 17 (manuscript at 139 n.295). Like the Commerce Clause, it spoke of powers. It authorized Congress to regulate hours and conditions of labor, to establish a minimum wage in any employment, and to regulate production and industry. 79 CONG. REC. 8470 (1935) (statement of Rep. Hildebrandt). The amendment, its champions declared, would "unmistakably establish the right of the people to have ... an industrial democracy." Id. Thus, the amendment's proponents seem to have thought that labor's collective rights were for democratic politics to support and sustain and for Congress to safeguard, even when the task at hand was drafting new constitutional text, and the slate was not one on which the Court already had written.

147. IRVING BERNSTEIN, TURBULENT YeARS 788 (1971) (describing organizing drives); Hansen, supra note 17, at 55 (noting that large employers engaged in a campaign of "organized resistance" to portions of the National Labor Relations Act securing workers' rights to organize and bargain collectively). 
(NLRB) ${ }^{148}$ Six out of six courts of appeals declared the Act invalid for trenching on states' rights and liberty of contract. ${ }^{149}$ Two legal and constitutional regimes - "each with a set of principles addressing issues all the way from the constitutional powers of Congress to the conduct of individual workers on the shop floor"-vied with one another in the nation's industrial centers. ${ }^{150}$ As these cases wended their way to the Supreme Court, Roosevelt campaigned for reelection, declaiming against the nation's "economic royalists" and "industrial dictatorship." ${ }^{151} \mathrm{He}$ accepted the Democratic nomination in the name of "the people's mandate" for new understandings of "liberty" and "equality" and of the citizens' legitimate claims on the state for social and economic rights, ${ }^{152}$ and he won the largest popular landslide in history.

Meanwhile, the CIO had embraced a new form of industrial action, the "sit-down strike," or factory occupation. ${ }^{153}$ Beginning in late November 1936, all the nation's big auto manufacturers were hit with full-blown factory occupations, shutting down operations for weeks and sometimes months. ${ }^{154}$ After a six-week nationwide sit-down forced concessions from General Motors, thousands of sit-down strikes spread to almost every industry and city in the nation. ${ }^{155}$ This disturbing new form of labor protest immediately became associated with the clash between the new rights promised by the Wagner Act and employers' common law and constitutional rights under the old order, and, so, with the Court-packing controversy. ${ }^{156}$ The strikers,

148. See Hansen, supra note 17, at 127 (describing employers' constitutional defenses, which lower courts embraced).

149. Myers v. Bethlehem Shipbuilding Corp., 88 F.2d 154, 156 (1st Cir. 1937); Foster Bros. Mfg. Co. v. NLRB, 85 F.2d 984, 986-87 (4th Cir. 1936); Fruehauf Trailer Co. v. NLRB, 85 F.2d 391, 392 (6th Cir. 1936); Pratt v. Stout, 85 F.2d 172, 177-78 (8th Cir. 1936); NLRB v. FriedmanHarry Marks Clothing Co., 85 F.2d 1, 2 (2d Cir. 1936); NLRB v. Jones \& Laughlin Steel Corp., 83 F.2d 998, 998 (5th Cir. 1936).

150. Pope, The Thirteenth Amendment, supra note 17 (manuscript at 134).

151. 5 ROOSEVELT, supra note 82, at 232-33.

152. Id. at 233 .

153. See generally Sidney Fine, Sit-Down: THE GENERAL Motors STRIKE OF 1936-1937 (1969) (detailing the emergence and spread of sit-down strikes in 1936 and 1937); ROBERT ZIEGER, THE CIO, 1935-1955, at 50 (1995) (noting that sit-down strikes offered advantages over outside strikes because they shut down production at once, minimized violence, and masked "union's numerical weaknesses").

154. See ZIEGER, supra note 153, at 50-53 (recounting strikes at General Motors and Chrysler).

155. See Hansen, supra note 17, at 5 (explaining the pervasiveness of the strikes and their effects on the Court).

156. See id. at 51-53 (arguing that the sit-down strikes had a profound influence on the "switch in time of 1937"). 
with their defenders in Congress and public debate, cast the sit-down strikes as claims for a new legal-constitutional regime recognizing workers' freedoms of organization and self-representation. ${ }^{157}$ The sitdown strikers at eight Chrysler plants in Detroit sent a widely publicized letter to Governor (soon-to-be Attorney General and then Justice) Frank Murphy. To Chrysler's dismay, this New Deal governor had refused to muster state troops against the strikers, allowing the sit-downs to continue. Not they, but their employers, the strikers declared, were guilty of lawlessness: ${ }^{158}$

While we were exercising our right to organize, we were opposed by one of the most vicious and unspeakable spy systems .... We were subject to intimidation.... [and] [o]ur members were fired for no other reason than that they had joined the union.... Then when we had built our union in spite of these obstacles the Chrysler Corporation refused to recognize us. And this refusal, Governor, was a lawless act. ${ }^{159}$

As soon as Chrysler ceased its defiance and abided by the new Wagner Act, recognizing "our right to organize" and "our rights to our jobs," the workers gladly would leave the plants. ${ }^{160}$ Senator Wagner too treated the sit-downers as on strike for the "fundamental right of a free worker" to organize and bargain collectively. ${ }^{161} \mathrm{He}$ laid blame for the strikes squarely on the employers and their "coldblooded sit-down against Federal law." "162

Meanwhile the New Republic reported that labor's "present calm willingness to face up to the Supreme Court [is] the most significant development since the election." ${ }^{163}$ Days after Jones \& Laughlin was announced, the leading liberal journal reported:

For ten weeks, Americans watched the momentous issues of "judicial reform" [Roosevelt's Court-packing plan in Congress] and "collective bargaining" move side by side across the national stage against a kaleidoscopic background of sit-down strikes, inflamed tempers, violent castigations of [the Court of] Nine Reactionary Old Men and equally fervid outbursts against judicial "packing." Last

157. Id.; Pope, The Thirteenth Amendment, supra note 17 (manuscript at 176-77).

158. Union's Letter to Murphy, N.Y. TIMES, Mar. 20, 1937, at A30.

159. Id.

160. Id.

161. 81 CONG. REC. 2940 (1937) (statement of Sen. Wagner).

162. Id. at 2945.

163. Washington Notes, New RePUBLIC, Nov. 25, 1936, at 110. 
week, the event which Americans had been anticipating...happened.... [T] he paths of "judicial reform" and "collective bargaining" crossed .... [and the Court upheld the Wagner Act.] [W]orkers no longer had to drop their tools and fold their arms to squeeze this concession [of the right to organize] from adamant bosses.... [T] Nine [Old Men] had about-faced, donned habiliments of liberalism, [and, in the same stroke] removed the need for "infusion of new blood." "164

Newsweek's headline read: "Judgment Day: Supreme Court Gives Its Blessing to Labor Relations Act and Hands Roosevelt a Victorious Defeat [on Court-packing]." ${ }^{165}$ Underneath was a picture that took up more than half of the page, of sit-downers perched in the windows of a factory. "Sit-downers," its caption read, "looked out at a future of court-given rights." 166

\section{A Triumph of the Political Constitution}

The political Constitution and the legislative vision of fundamental rights seemed vindicated. "In the end, FDR and the New Dealers had to depend on neither the amendment process nor the courtpacking plan to 'save the Constitution from the Court." "167 To contemporaries it seemed that the interpretive task of determining whether the constitutional vision of the sit-downers or the employers would prevail had been accomplished through the mundane intermediary of the interstate Commerce Clause. ${ }^{168}$ While Congress debated the Court-packing plan against a background of massive sit-downs, the Court made its famous "switch in time." Soon the appointments of New Dealers to the Court would turn acquiescence into assent to the New Deal "mandate."

The Court was not seriously urged nor did it seriously consider resting the future of court-given rights on the rights-affirming Reconstruction Amendments. The jurisdictional compromise we now lament happened almost by default, by dint of the Court's colonization of those amendments, and the drafters' consequent shunning of them,

164. Storm-Clouds in Legislative Sky: “Judicial Reform," "Collective Bargaining” Twin Headaches, LiTERARY Dig., Apr. 24, 1937, at 3.

165. Judgment Day: Supreme Court Gives Its Blessing to Labor Relations Act and Hands Roosevelt a Victorious Defeat, NEWSWEEK, Apr. 17, 1937, at 7.

166. Id.

167. Forbath, supra note 6, at 67.

168. Hansen, supra note 17, at 121-30 (explaining that the Court had broadened its conception of the interstate Commerce Clause). 
and by virtue of the political and intellectual isolation of Andrew Furuseth, James Gray Pope's solitary hero in the era's ranks of constitutional advocates.

Chief Justice Hughes did echo Senator Wagner in dubbing the rights to organize, choose representatives, and bargain collectively "fundamental rights." ${ }^{169}$ More revealingly, though, as New Dealers in Congress carried on with their efforts to renovate the fundamental rights of citizenship, the Wagner Act and the freedoms it protected would figure as far-reaching precedent, redefining the constitutional meaning of work.

\section{The COUNTERREVOLUTION AND THE DEFEAT OF SOCIAL CITIZENSHIP}

The New Dealers, then, had a constitutional mandate, but it was not a mandate to expand government, as such; it was a mandate to "protect the citizen in his right to work and his right to live.," What became of this mandate?

This much is certain. Although the Warren and Burger Courts fashioned statutory presumptions and procedural protections in favor of welfare provisions, starting in the late 1970s the Court cut these solicitous strands of doctrine well short of any substantive welfare rights, declaring that the Constitution confers "no affirmative right to governmental aid, even where such aid may be necessary to secure life, liberty, or property." ${ }^{171}$ In 1996, a Democratic president signed into law a statute ending the federal guarantee of welfare to eligible parents and children. ${ }^{172}$ A year later, a leading liberal constitutional theorist wrote that today, the idea of constitutional welfare rights seems "off the table" and "off-the-wall"; ${ }^{173}$ another noted that constitutional welfare rights were an idea that "simply doesn't live in this world anymore."174

169. NLRB v. Jones \& Laughlin Steel Corp., 301 U.S. 1, 33 (1936) (“"TT]he statute goes no further than to safeguard the right of employees to self-organization and to select representatives of their own choosing for collective bargaining or other mutual protection without restraint or coercion by their employer. That is a fundamental right.").

170. 5 RooseVelt, supra note 82, at 234. Portions of Part II draw heavily on Forbath, supra note 6 .

171. DeShaney v. Winnebago County Dep't of Soc. Servs., 489 U.S. 189, 196 (1989). This history is recounted in Forbath, Constitutional Welfare Rights, supra note 17.

172. Personal Responsibility and Work Opportunity Reconciliation Act of 1996, Pub. L. No. 104-193, 110 Stat. 2105 (repealing Aid to Families with Dependent Children).

173. J.M. Balkin, Agreements with Hell and Other Objects of Our Faith, 65 FordHAM L. REV. 1703, 1732 (1997).

174. Lessig, supra note 18, at 1509-10. 
Such statements would be unimaginable had the New Dealers managed to bring social citizenship principles from the reform precincts to the center of our constitutional tradition. Indeed, welfare rights seem a narrow and truncated version of their understanding of social and economic citizenship rights, which centered around the right to work and make a decent living. One cannot help but think that this broader work-based understanding is better rooted in the nation's constitutional identity and the Antislavery and Free Labor soil from which the Reconstruction Amendments grew. To understand the present exile of the "right to live" and to make a living, we must examine the fate of the New Deal mandate.

\section{A. The Solid South, the Counterrevolution, and the Fracturing of Social Citizenship}

That fate was decided by the sway of Jim Crow over the politics of New Deal lawmaking. The nation's betrayal of Reconstruction prevented the legislative enactment of the New Deal vision of national citizenship. Measures instituting rights to decent work and social provision for all Americans enjoyed broad support, ${ }^{175}$ yet they expired in Congress. Thanks to their numbers, their seniority, and their control over key committees, southern Democrats had a hammerlock on Congress. ${ }^{176}$ The Solid South's national representatives generally supported the New Deal until the late 1930s. They demanded, however, that New Deal social provision and labor standards respect states' rights, by resting on state, and not national, administration and standard setting. Also, they insisted that key bills exclude the main categories of southern labor, else Congress would fall guilty of doing what it had done so often in the past, using legislation to "overcome the splendid gifts of God to the South." "177 If southern agricultural labor were covered, how "were they going to get blacks to pick and chop cotton when Negroes [on federal work programs] were

175. See Lizabeth Cohen, Making a New Deal: Industrial Workers in Chicago, 1919-1939, at 252-83 (1990) (describing and documenting a New Deal-inspired sense of entitlement to jobs and social provision among millions of American workers).

176. Political scientist V.O. Key long ago described how the Dixiecrats exercised this power to veto civil rights legislation. V.O. KEY, JR., SOUTHERN POLITICS IN STATE AND NATION 329-44 (1949). But the Dixiecrats used their veto power more broadly.

177. See Gavin Wright, Old South New South: Revolutions in the Southern ECONOMY SINCE THE CIVIL WAR 219 (1986) (quoting Congressman Ellison "Cotton Ed" Smith assailing the administration's original Fair Labor Standards bill). 
receiving ... more than twice as much as they had ever been paid." ${ }^{178}$ The outrage to "our region" also "outrage[d] the Constitution," by threatening to "set up a dangerous and all-powerful board... in Washington" in "utter violation of States' rights, local selfgovernment, [and] local self-determination of our own sociological and economic problems." ${ }^{, 179}$

At stake was the South's labor market, with its unique fusion of class and caste relations and its low wages. ${ }^{180}$ Social Security is a prime illustration of the Solid South's sway over reforms affecting that market. Roosevelt's Committee on Economic Security fashioned the administration's proposals to appease the Southern Bourbons. ${ }^{181}$ The Committee's blueprints adopted state-level autonomy-though with national minimum standards - in both unemployment insurance and assistance for the needy aged, dependent children, and blind. Only the old-age benefits program would be purely federal. ${ }^{182}$ Nonetheless, when the blueprints arrived in Congress, the Dixiecrats demanded more from the sponsors of the administration bill. National standards for unemployment and old-age insurance also vanished and the core principle of a national commitment to include all employed persons in the unemployment and old-age insurance schemes was abandoned. ${ }^{183}$ Finally, the Dixiecrats expelled agricultural and domestic workers from the nation's core social insurance programs, thereby expelling the majority of black Americans, who worked in these two sectors. ${ }^{184}$

178. Harvard SitKoff, A New Deal for Blacks: The Depression Decade 104 (1978) (quoting Senator Carter Glass of Virginia).

179. 82 CONG. REC. A441 (1937) (statement of Rep. Cox).

180. See generally Ira Katznelson et al., Limiting Liberalism: The Southern Veto in Congress, 1933-1950, 108 POL. SCI. Q. 283, 296 (1993) (finding that, though Dixiecrats at first supported much of the Democratic party's "social democratic agenda," they consistently sided with Republicans on labor and civil rights issues).

181. See Arthur Altmeyer, The Formative Years of Social Security 15 (2d ed. 1968) (noting that, in crafting the proposal, the Committee had to consider "congressional reactions"); FrAnCIS PERKINS, THE ROOSEVElT I KNEW 291 (1952) (explaining why the Committee decided to create a state-federal system for social security).

182. See PERKINS, supra note 181, at 291-92 (exploring the Committee's internal wrangling in deciding to have a federal system for old-age benefits).

183. See AltMEYER, supra note 181, at 36 (noting that southerners objected to national administrators telling states what to do); Kenneth Finegold, Agriculture and the Politics of U.S. Social Provision: Social Insurance and Food Stamps, in POLITICS OF SOCIAL POLICY IN THE United STATES 199, 212 (Margaret Weir et al. eds., 1988) [hereinafter Politics] (detailing the sequence of events that caused national coverage to be abandoned).

184. See Finegold, supra note 183, at 212 (noting that three-fifths of blacks were either "domestic or agricultural workers"). 
So it went across the array of core reforms. Whether the arena was agricultural or industrial recovery, industrial relations or labor standards, broad, inclusive bills-bills with national rather than local standards and administration-enjoyed solid support from the northern Democrats (and from disenfranchised southern blacks and poor whites). But the bills failed. For his first term, Roosevelt seemed entirely willing to oblige his party's powerful southern bloc and the "racial civilization" they prized. ${ }^{185}$ Then, however, as the 1936 election approached and business opposition to the New Deal intensified, Roosevelt grew more attentive to two crucial constituencies: the insurgent new industrial unions of the CIO and the black voters of the large cities of the North. As these groups began to bulk large in his 1936 reelection bid, Roosevelt's social and economic rights talk grew more universal and robust-and the southern attacks began. Governor Talmadge of Georgia called a "Grass Roots" convention to uphold the Constitution against "Negroes, the New Deal and ... Karl Marx." ${ }^{186}$ For his part, Senator Carter Glass of Virginia challenged the white South to show "spirit and courage enough to face the new Reconstruction era that northern so-called Democrats are menacing us with." 187

In the fall of 1937, after the Court had handed down West Coast Hotel Co. v. Parrish ${ }^{188}$ and Jones \& Laughlin, and its steadfastness in upholding the old Constitution seemed to be crumbling, the New Deal's foes in Congress were galvanized. The old Constitution found a new redoubt, and the counterrevolution authored a manifesto. A group of conservative southern Democrats in the Senate met with like-minded Republican senators to consider a more formal alliance against the New Deal. ${ }^{189}$ If the judicial safeguards for state sovereignty and individual liberty were eroding, they agreed, they must invest renewed vigor in the century-old Constitution of congressional constitu-

185. James T. Patterson, Congressional Conservatism AND THE NeW DeAl: The Growth OF THE CONSERVATIVE COALITION IN CONGRESS, 1933-1939, at 278-79 (1967); SITKOFF, supra note 178, at 103 (explaining that Roosevelt did little to "upset local elites" or further the cause of "Negro rights"); NANCY WeISS, FAREWELl TO THE PARTY OF LINCOLN: BLACK POLITICS IN THE AGE OF FDR 243 (1983) (noting that Roosevelt did little to support the antilynching bill); Katznelson et al., supra note 180, at 284 (detailing how southern representatives had to engage in a "balancing act" with Roosevelt to secure southern economic aid while protecting "white privilege").

186. SITKOFF, supra note 178 , at 106.

187. Id. at 109-10.

188. 300 U.S. 379 (1937).

189. PATTERSON, supra note 185 , at 198-210. 
tional precedent and practice. They drafted a "statement of principles" $" 190$ - it became known as the "Conservative Manifesto"- that reaffirmed their devotion to the Constitution of states' rights ("the vigorous maintenance of States' rights, home rule, and local selfgovernment"), ${ }^{191}$ liberty of contract (and the "common law principles of free men"), ${ }^{192}$ and the property rights of the owners of capital ("the constitutional guaranties of the rights ... of property"). ${ }^{193}$ The attempt at forming a new conservative party foundered, but the coalition and its role as bulwark for the old Constitution held firm and prevailed.

The conservative coalition managed to cripple or undo administration measures in the areas of labor reform and social insurance. ${ }^{194}$ World War II, in turn, brought labor shortages and a burgeoning of national governmental controls on local and state economies. With this, southern congressmen openly joined ranks with the minorityparty Republicans to thwart Roosevelt's executive reorganization plan, to gut the administration's 1945 Full Employment Bill, ${ }^{195}$ and to abolish the National Resources Planning Board (NRPB). ${ }^{196}$

The conservative coalition's accomplishments in destroying these agencies and thwarting these measures meant that Roosevelt's famous "second, economic Bill of Rights" legislative and institutional embodiments, and the maturation of the

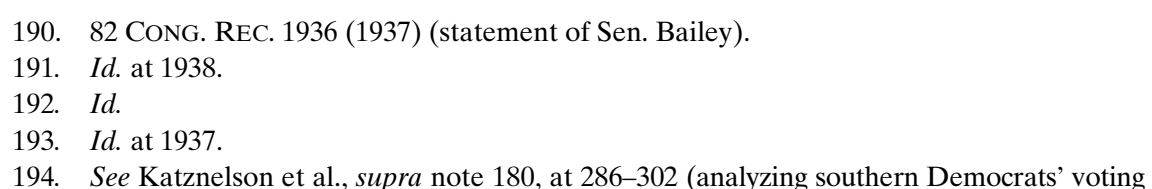
patterns in eighty-nine Senate and sixty-one House roll call votes on critical New Deal bills and amendments); see also STEPHEN BAILEY, CONGRESS MAKES A LAW: THE STORY BEHIND THE EMPLOYMENT ACT OF 1946, at 220-34 (1950) (detailing how Dixiecrats and Republicans joined forces to eliminate the central rights-conferring and policy-making features of the original Full Employment Bill); Marion Clawson, New Deal Planning: The National Resources PLANNING BOARD 225-36 (1981) (describing the demise of the National Resources Planning Board).

195. See infra notes 204-06 and accompanying text. The most detailed legislative history of the administration's Full Employment Bill is provided by BAILEY, supra note 194.

196. See Clawson, supra note 194, at 225-36 (noting that conservative southern Democrats led a campaign to dismantle the National Resources Planning Board).

197. See Franklin D. Roosevelt, Message to the Congress on the State of the Union (Jan. 11, 1944), reprinted in 13 FrankLIN D. RoOSEVElT, THE Public PAPERS AND AdDRESSES OF FRANKLIN D. RoOSEVELT 32, 41-42 (Samuel I. Rosenman ed., 1950) (outlining eight economic rights "under which a new basis of security and prosperity can be established for all"); see also Franklin D. Roosevelt, Address to the Congress on the State of the Union, reprinted in 12 Franklin D. RoOsevelt, The Public PAPERS AND AdDREsSes OF Franklin D. RoOSEVElT 21, 30-31 (Samuel I. Rosenman ed., 1950) (again, expounding Roosevelt's new economic rights, including the right to work and assurance against major economic hazards). 
idea of legislated fundamental rights would cease. The administration's defeated social insurance bills sought to remedy the many gaps, exclusions, and anomalies in the Social Security Act. ${ }^{198}$ They envisioned restoring the Committee on Economic Security's original provision for national administration of federal unemployment insurance. The NRPB's proposals also echoed the Committee on Economic Security in calling for the assurance of an "American standard" of economic security as a right of every citizen. Every citizen, through private or public employment or through public aid, the NRPB stipulated, should receive at least the minimum wage specified by the 1938 Fair Labor Standards Act. ${ }^{199}$ And, to the ire of congressional conservatives, who declaimed against "Roosevelt constitutional tyranny," 200 the administration's executive branch reform bills also envisioned new administrative capacities in the executive branch to oversee fiscal policies, work programs, and public investment in the name of full employment.

Roosevelt met with the NRPB as they formulated the Declaration of Principles for their prominent report, Development of National Resource-Report for 1942. Roosevelt adopted the Declaration for his speeches. ${ }^{201}$ With the Board, Roosevelt advocated a "second, economic Bill of Rights," above all, an unequivocal federal commitment to full employment, as well as expanded social insurance and public investment. ${ }^{202}$ In addition to "adequate food and clothing and recreation," medical care, and "a decent home," Roosevelt's "Bill of Rights" included "[t]he right to a useful and remunerative job" and "the right to earn enough," with all of these rights existing "regardless of station, race, or creed." ${ }^{203}$

The administration's Full Employment Bill set forth an unequivocal federal commitment to full employment and provided for the data-

198. See Clawson, supra note 194, at 136-40 (describing Security, Work, and Relief Policies, the National Resources Planning Board's report which recommended expanded government support for health, education, and welfare).

199. NAT'L Res. Planning BD., SeCURity, Work, AND Relief Policies 514-15 (1942).

200. 83 CONG. REC. A1379 (1938) (statement of Sen. Bridges) (opposing Roosevelt's executive reorganization plan).

201. See Franklin D. Roosevelt, The President Transmits to the Congress a Report on Development of National Resources (Jan. 14, 1942), in 11 FrankLIN D. RoOSEVElT, THE PUbLiC PAPERS AND ADDRESSES OF FrANKLIN D. RoOSEVElT 52, 52-54 (Samuel I. Rosenman ed., 1950) (noting that Roosevelt's "Economic Bill of Rights" originally appeared in the 1942 report in a slightly different form).

202. See NAT'L RES. PLANNING BD., supra note 199, at 1-4 (outlining the needs for available work and public assistance).

203. 13 RoOSEVELT, supra note 197, at 32, 41. 
gathering and policymaking capacities commended by the NRPB ${ }^{204}$ But the bill met defeat, like the other late 1930s and early 1940s bills that Roosevelt and congressional New Dealers championed for expanded social insurance and public investment. ${ }^{205}$ They all embodied unconstitutional surrenders of legislative powers in the conservatives' view, as well as infringements on individual liberty and states' rights. But for this, these measures would have laid an institutional foundation for active national labor market and full employment policies. ${ }^{206}$ These defeated and dismantled laws, agencies, and innovations were ones that would have sustained the political Constitution of social and economic rights and generated the new institutional capacities and commitments embodied in the "all-important right to work," in "the right to earn a decent livelihood," in the right "to opportunity and advancement," and in the right "to train and retrain."

The constitutional bad faith-the willful blindness toward the Reconstruction Amendments' condemnation of racial caste-that for half a century enabled both parties and all three branches of the federal government to condone or support Jim Crow and disenfranchisement produced the anomaly of a reactionary core, the Solid South, at the heart of Roosevelt's New Deal liberal coalition. In the face of the Fifteenth Amendment's bar on race-based disenfranchisement, the southern state governments disenfranchised black citizens through such racially "neutral" measures as the poll tax and literacy tests. From the Southern oligarchs' perspective, these had the additional

204. See NAT'L RES. PLANNING BD., supra note 199, at 485 (calling for a body charged with the continuous monitoring of the operation of full employment, public investment, and publicaid programs).

205. See Clawson, supra note 194, at 225-36 (describing the demise of the National Resources Planning Board); Katznelson et al., supra note 180, at 297 (observing increased southern resistance to New Deal programs during the wartime Congresses).

206. See BAILEY, supra note 194, at 53-54 (noting that a report accompanying the first public printing of the Full Employment Bill stated that "the so-called right to a job is a meaningless figure of speech unless our government assumes the responsibility for the expansion of our peacetime economy"); MARGARET WeIR, POLITICS AND JOBS: THE BOUNDARIES OF EMPLOYMENT POLICY IN THE UNITED STATES 27-28 (1992) ("In less than a decade, the United States had moved from a position of international leadership in employment policy innovation to a stance that reflected severe doubts about the desirability of active government measures to reduce unemployment."); Ira Katznelson \& Bruce Pietrykowski, Rebuilding the American State: Evidence from the 1940s, 5 STUD. AMER. POL. DEV. 301, 325 (1991) ("Governmental economic policies would be driven by the overarching aim of full employment.").

207. Full Employment Bill: Hearings on S. 380 Before a Subcomm. on Banking and Currency, 79th Cong. 2, 4, 10, 59 (1945), quoted in Forbath, supra note 6, at 75; see also PHILliP HARVEY, SECURING THE RIGHT TO EMPLOYMENT: SOCIAL WELFARE POLICY AND THE UNEMPLOYED IN THE U.S. 106-10 (1988) (describing the provisions of the original form of the Full Employment Bill). 
benefit of also disenfranchising a majority of the region's poor and working-class whites, which enabled the Dixiecrat oligarchy to choose the bulk of the South's congressional delegation. The upshot was the derailing of the New Deal "revolution" by a Dixiecrat-led counterrevolution.

Put simply, the absence of political citizenship led to the defeat of social citizenship in America. Not only were most black Americans excluded from the benefits of the main New Deal programs, but this constitutional bad faith at black America's expense also deprived all Americans of the institutional foundations and political-constitutional legacy of social citizenship. Broad social and economics rights talk fell into disuse after the decisive defeats that the New Deal agenda suffered in the 1940s. Blocked by the Dixiecrats at every legislative crossroad, the CIO, social citizenship's only powerful, organized constituency, gradually abandoned its efforts to "complete the New Deal."

\section{B. The Civil Rights Movement of the New Deal Era: Civil Rights and Social Rights, "Two Sides of the Same Equation"}

Roosevelt and the New Dealers did not entirely repress or ignore the contradiction between their professed goal of social citizenship and their pact with Jim Crow. A labor-based civil rights movement emerged during these years, linking the struggles for racial justice and social citizenship. The White House, the Justice Department, and key congressional New Dealers lent that effort a genuine measure of support. ${ }^{208}$ The movement was an important seedbed for the 1960s civil rights movement, but also importantly different from it, not only in its institutional base, but also in its constitutional vision and its litigation and reform strategies. These strategies reflected the New Deal's focus on work and economic inequality and frequently took the form of seeking, through legislation and litigation, to bring black America into the fold of New Deal social reforms, and more broadly into the fold of full citizenship via a reconstituted Democratic party. Surprisingly, in view of the Thirteenth Amendment's marginality in later civil rights law, New Deal civil rights lawyers set great store by the Thirteenth Amendment, reinvigorating its historical nexus of race

208. See SiTKOFF, supra note 178, at 169-89 (quoting the National Industrial Recovery Act's guarantee of employees' right to organize and bargain through their own representatives, which gave black workers their first opportunity to vote as a national group). See generally PATRICIA Sullivan, DAYs OF HoPE: RACE AND DemocRACY IN THE NEW DEAL ERA (1996) (describing numerous New Deal leaders and initiatives assisting African-American organization and civil rights campaigns). 
and free labor by litigating cases that joined questions of racial justice and the exploitation and coercion of labor. ${ }^{209}$ Appealing to a Court of New Deal Justices, these lawyers also brought realism to civil rights jurisprudence through the remarkable treatment of "state action" in Shelley v. Kraemer, ${ }^{210}$ and they envisioned extending that treatment to other arenas of racial subordination. ${ }^{211}$ Above all, they fashioned a vision of civil rights more concerned with substantive social and economic inequality than the civil rights jurisprudence we know today.

The NAACP, however, with its litigation and social work orientation and its middle-class leadership, seemed ill-equipped to act in the workplaces and working-class neighborhoods where black Americans fought their most decisive battles in the New Deal era. The vanguard of civil rights struggles instead consisted of the half-million black workers who joined CIO unions, with their resounding demand, "Equal rights for Negro workers." ${ }^{212}$ As a study by one of the NAACP's chief foundation funders uneasily concluded, "the characteristic movements among Negroes are now for the first time becoming proletarian." 213 A reporter for Crisis, the NAACP's national journal, observed that the CIO had become a "lamp of democracy" throughout the old Confederate states. "The South has not known such a force since the historic Union Leagues in the great days of the Reconstruction era." ${ }^{214}$

In contrast to the AFL, then, the new CIO actively recruited black workers, who proved crucial to industrial organizing in the North and South. ${ }^{215}$ It also helped spawn a labor-led voting rights movement across

209. The key work here is Risa Goluboff's important research in Goluboff, supra note 17, at $1668-85$.

210. 334 U.S. 1, 18 (1948) (holding that court enforcement of restrictive covenants constitutes state action).

211. See MARK TUSHnet, MAKing Civil Rights LAw 308-10 (1994) (discussing attempts to apply the Shelley doctrine to sit-ins at discriminatory restaurants).

212. Robert Korstad \& Nelson Lichtenstein, Opportunities Found and Lost: Labor, Radicals, and the Early Civil Rights Movement, 75 J. AM. HIST. 786, 787 (1988).

213. Richard Dalfiume, The Forgotten Years of the Negro Revolution, 55 J. AM. HIST. 90, 100 n.47 (1968).

214. Harold Preece, The South Stirs, 48 CRISIs 317, 318 (1941).

215. See Horace Cayton \& GeORge Mitchell, Black Workers and the NeW Unions 80-81 (1939) ("[T]he American Federation of Labor .. . [was not] willing at that time to consider problems of Negro labor.”); HERBERT NORTHRUP, ORGANIZED LABOR AND THE NEGRO 8, 14 116 (1944) (setting forth the respective policies on racial discrimination of the American Federation of Labor and the Congress of Industrial Organizations); ZIEGER, supra note 153, at 83-85 ("Thus, to the men who launched the [Congress of Industrial Organizations], the importance of black workers in industrial America was clear."). But see NELSON LICHTENSTEIN, The Most Dangerous Man in Detroit: Walter Reuther AND THE FATE OF AMERICAN LABOR 91 (1994) ("The National Association for the Advancement of Colored People, the Urban League, and the black church were led by members of the black community who were skeptical of the [Congress of Industrial Organizations] and still oriented toward Ford and other paternalistic 
the South. And it underwrote A. Philip Randolph's union-sponsored "March on Washington for Jobs and Equal Participation in National Defense." 216 In 1941, Randolph called on "Negro America" to march on the Capitol: "[I]f American democracy will not give jobs to its toilers because of race or color ... it is a hollow mockery.",

Roosevelt responded with the Fair Employment Practices Committee (FEPC) to address job discrimination in defense industries. ${ }^{218}$ The FEPC was weak, but it was the first civil rights agency in the federal government since the Freedmen's Bureau of the Reconstruction era, and its investigations inspired and legitimated black protest. ${ }^{219}$ Beginning in 1943, Randolph addressed rallies demanding a permanent FEPC to be organized like the NLRB, with similar authority to identify and adjudicate rights violations. ${ }^{220}$ Like the Wagner Act, this law would secure "the right to work without demeaning discrimination."221 The one safeguarded the "dignity of union membership and industrial democracy"; the other would protect the "dignity of fair employment." 222 Bills to transform the wartime FEPC into a permanent federal agency came before Congress in $1945,{ }^{223}$ the same year as the administration's Full Employment Bill. The latter was championed as a measure to enact Roosevelt's "second Bill of Rights." The social right to a "job for all who can work," and the civil "right to work, irrespective of ... race, color and creed" were "two sides of the same equation"-both of them parts of the "economic rights of American citizenship.",224

[Congress of Industrial Organizations] and still oriented toward Ford and other paternalistic white elites.").

216. Paula Pfeffer, A. Philip Randolph, Pioneer of the Civil Rights Movement 45-47 (1990) (discussing how the systematic exclusion of blacks from job opportunities inspired the March).

217. A. Philip Randolph, Call to Negro America (n.d.), in C.R. Dellums PAPERS, Bancroft Library, U.C. Berkeley, Carton 23, Folder: March on Washington, Statement of Facts, cited in Forbath, supra note 6 , at 82 n. 365 .

218. See generally MERL E. ReED, SEedtime FOR the Modern Civil Rights Movement: THE PRESIDENT's COMMITTEe ON FAIR EMPLOYMENT PRACTICE, 1941-1946 (1991) (recounting the history of the Fair Employment Practices Committee).

219. See generally id.

220. Daniel Bell, A. Philip Randolph Leads Drive for Permanent FEPC, NEw LEADER, Sept. 18,1943 , at 1 .

221. Id.

222. Id.

223. See REED, supra note 218, at 321-43 (discussing the plans for reconversion of the Fair Employment Practices Committee).

224. 90 CONG. REC. A3031-32 (1944) (extension of remarks of Rep. LaFollette); 91 ConG. REC. A2882 (1945) (extension of remarks of Rep. Patterson). 


\section{The Constitution of the Counterrevolution}

The Dixiecrats unfurled a host of objections to the bills proposing a permanent FEPC, beginning with criticism of the political motivations they saw behind the bills. Northern "so-called Democrats" were pandering to "get the votes of a certain race in this country.",25 That was the motive behind the raft of civil rights bills-antilynching bills, anti-poll tax bills, bills bringing black occupations under Fair Labor Standards coverage or setting national minimums for those standards, and now the FEPC bills- that northern New Dealers like Wagner and LaFollette had been trying to foist on Congress since the 1937-38 rift and the emergence of a full-blown conservative coalition. ${ }^{226}$ Not only were they wooing the votes of blacks in northern cities like Wagner's New York, but even more ominously they craved the votes of southern blacks, as one leading Dixiecrat put it, "[i]n order ... that I will not have an opportunity to fill this seat again." 227 This characterization was not wrong. With widely varying degrees of resolve, the northern New Dealers tried to revive Reconstruction's promise of racial equality and equal citizenship. They did so from principle, but also because they needed to reconfigure their party if they meant to complete their social citizenship agenda; they needed to reconstitute the Democratic party as a party of New Deal liberalism. Like the Reconstruction Republicans, they had the politicalconstitutional aim of enfranchising the black and poor white South, which they imagined as a new southern base for their party.

Not only were the motivations behind the FEPC bills unsavory to the Dixiecrats; the idea of national legislation against private employment discrimination also was "in palpable violation of the Constitution." ${ }^{228}$ But "[w]hat is the Constitution between friends," one Dixiecrat acidly inquired, "especially if the question has to do in some way, directly or indirectly, with the suffrage of a Negro?",229 The Bourbon congressman explained that insofar as the proponents of a permanent FEPC sought to rest the measure on the Fourteenth Amendment, by declaring that the "right to work" free from discrimination was a privilege or immunity of national citizenship, they

225. 81 CONG. REC. 7882 (1937) (statement of Sen. Smith).

226. Id.

227. Id.

228. 94 CONG. REC. A4280 (1948) (extension of remarks of Rep. Williams).

229. Id. at $\mathrm{A} 4281$. 
flouted the Slaughter-House Cases $^{230}$ on the scope of those privileges and immunities. What was more, the drafters were ignoring the state action requirement of the Civil Rights Cases, ${ }^{231}$ and to the extent they purported to rest the bills on the Commerce Clause, they could not prevail unless Congress could now do anything at all under that clause. Surely that Clause did not authorize Congress to reach deeply into the realm of private life (compelling unwanted racial association) and the rights of private property beyond where even the states "operating in the vast realm of their reserved sovereignty" could properly venture. ${ }^{232}$ Even the states, as one Republican argued, could not enact the FEPC antidiscrimination norm without destroying "the right of free choice in hiring, discharging, or promoting employees."

The House sponsor of a permanent FEPC, Indiana Representative Charles LaFollette, responded often and at length to these various objections. Regarding "free choice in hiring," he pointed out that the Court already had upheld a federal statutory intrusion on that freedom in the form of the Wagner Act's outlawing both yellow-dog contracts and the discharge of a worker for union affiliation. The Court,

held it was unlawful to refuse to employ a man because of his... union activities... . From which it seems to me, it follows ... as a matter of constitutional authority that Congress has the power to declare a thing to be discrimination, which the Supreme Court has held to be irrelevant and invidious. ${ }^{234}$

LaFollette and many others went further, expounding the Wagner Act as a fundamental rights-affirming text that embodied a new conception of constitutional property claims. ${ }^{235} \mathrm{He}$ reasoned, again, as though the statute rested on the Fourteenth Amendment. The Act, on this reading, endowed the "the right of employment in industry or the right to work" with "the dignity of at least a quasi property right." ${ }^{236}$ The "effect of the rulings of the Supreme Court ... in upholding the provisions of the Wagner Act," was "to take a step forward to the creation of

230. 16 U.S. (1 Wall.) 36, 82 (1873) (holding that the states should have the power to regulate "civil rights- the rights of person and of property").

231. 109 U.S. 3,24 (1883).

232. 91 CONG. REC. 3680 (1945) (statement of Rep. Hays).

233. 94 CONG. REC. A4282 (1948) (extension of remarks of Rep. Williams).

234. 91 CONG. REC. 3673-74 (1945) (extension of remarks of Rep. LaFollette).

235. 90 CONG. REC. A3031-32 (1944) (extension of remarks of Rep. LaFollette).

236. Id. at $\mathrm{A} 3032$. 
a new concept of property." ${ }^{237}$ From this, LaFollette claimed a warrant for Congress to protect this "right to work at gainful employment," at least against invidious discrimination. ${ }^{238}$ There remained the state action requirement. But this he swept away as an artifact of a laissez-faire era, no longer constraining in an age of positive government. If the nineteenth-century Constitution forbade laws or customs requiring or upholding private race discrimination, and Congress could sanction such laws or customs, then today it followed that Congress "also has the affirmative power to treat affirmatively with those discriminations and to prohibit them."239

Other FEPC proponents reached the same result via Justice Harlan's Civil Rights Cases dissent. There Justice Harlan suggested that the Fourteenth Amendment's grant of a national citizenship is itself a source of affirmative power to outlaw private, racially motivated deprivations of equal civil rights, ${ }^{240}$ such as the right to contract; there too he suggested that state action may be found where the private actor is a creature of state law, like a corporation. ${ }^{241}$ Congress, too, in statutes like the Wagner Act, had underscored the publicly constructed character of the corporation and of its private power over employees. ${ }^{242}$ Perhaps the New Deal Court, having found federal authority to reach corporate conduct in so many once-sacrosanct arenas, would embrace Harlan's theory. ${ }^{243}$ At any rate, this was a theory of the drafters of the Senate FEPC bill, in providing that the "right to work and seek work without discrimination ... is declared to be an immunity, of all citizens of the

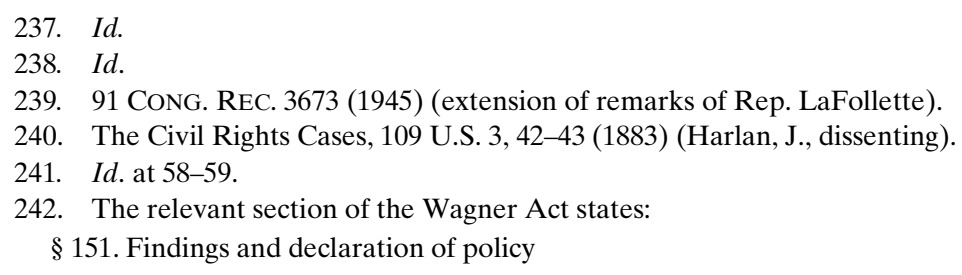

The inequality of bargaining power between employees who do not possess full freedom of association or actual liberty of contract, and employers who are organized in the corporate or other forms of ownership association substantially burdens and affects the flow of commerce, and tends to aggravate recurrent business depressions, by depressing wage rates and the purchasing power of wage earners in industry and by preventing the stabilization of competitive wage rates and working conditions within and between industries.

29 U.S.C. $\$ 151$ (1994).

243. See, e.g., Osmond K. Fraenkel, The Federal Civil Rights Laws, 31 MINN. L. Rev. 301, 315-16 (1947) (expressing hope that Harlan's dissent would be persuasive, given "recent judicial authority" barring unions' discriminatory use of government-granted bargaining authority). 
United States, which shall not be abridged by any State or by an instrumentality or creature of the United States or any State." ${ }^{244}$

\section{The Counterrevolution Triumphant}

Introduced again and again from 1945 onward, the administration's FEPC bills either died at the hands of Dixiecrat committee chairmen or were vanquished by Dixiecrat filibusters, wherein the old Constitution was fully aired. ${ }^{245}$ The Dixiecrats also killed the social right to work by gutting the administration's Full Employment Bill in committee. ${ }^{246}$ These defeats hardly shocked the New Dealers who had been championing racial justice as well as social reform in Congress and the administration. Since the late 1930s, administration figures like Eleanor Roosevelt and Secretary of Agriculture Henry Wallace and lawmakers like Wagner and LaFollette had been contending that the future of New Deal reform hinged on attacking Jim Crow and southern disenfranchisement. ${ }^{247}$ They succeeded in prodding Roosevelt to step into a number of 1938 primary elections in the South, with the aim of defeating reactionary Democrats. ${ }^{248}$ Roosevelt openly assailed the South's congressional bloc for stymying New Deal reforms simply because they threatened the South's "feudal economic system."249

The president found enthusiastic support among southern labor and tenant farmers, but this support did not translate into defeat for the reactionaries, ${ }^{250}$ for the poll tax and other restrictions kept these supporters from voting. ${ }^{251}$ Roosevelt's campaign to elect southern liberals did inspire the founding of the Southern Conference on Human Welfare (SCHW), a biracial coalition of southern trade unionists and civil

244. S. 101, 92nd Cong. § 2 (1946).

245. Thwarted in Congress, New Deal conceptions of federal civil rights had other advocates in the Department of Justice. Risa Goluboff chronicles the activities of the Department's Civil Rights Section during the 1940s, when, in her words, "race and labor coexisted as two parts of the Section's mandate" and its civil rights practice. Goluboff, supra note 17, at 1684. Indeed, it was Senator Robert LaFollette's famous investigations into the violation of the civil rights and civil liberties of industrial workers by anti-union employers that prompted Attorney General Frank Murphy, Michigan's governor during the sit-down strikes, to create the new section in 1939. Id. at 1617-18.

246. BAILEY, supra note 194, at 165-67; REED, supra note 218, at 340-41.

247. See Sullivan, supra note 208, at 59 (noting that, because "the poll tax and other restrictions kept most blacks and a majority of low-income whites from voting," the people in the South most likely to support the New Deal were also those that were least likely to participate in elections).

248. Id. at 65 .

249. Id. at 62 .

250. Id. at 67 .

251. Ralph Bunche, The Political Status of the Negro in the Age of FDR 384-437 (1973). 
rights activists funded by the CIO to attack disenfranchisement and carry out the liberal realignment of the Democratic party. ${ }^{252}$

"There is another South," SCHW President Clark Foreman assured the CIO Executive Committee, "composed of the great mass of small farmers, the sharecroppers, the industrial workers white and colored, for the most part disenfranchised by the poll tax and without spokesmen either in Congress, in their state legislatures or in the press." ${ }^{253}$ This South, he claimed, was the great majority of the region's population. ${ }^{254}$ Were this majority mobilized and enabled to vote, the South would become "the most liberal region in the Nation.",255

In 1944, the Supreme Court decided Smith v. Allwright, ${ }^{256}$ declaring the all-white primary unconstitutional, ${ }^{257}$ this combined with a generous influx of money and black and white organizers from the CIO to produce an extraordinary voter registration drive in the South. ${ }^{258}$ New Dealers of the North and South hoped to witness a test of Foreman's hypothesis that a latent, biracial, liberal majority existed among the South's disenfranchised citizens. In a few southern states like Alabama and Georgia, the number of black and poor white voters increased severalfold. ${ }^{259}$ A black leader in Birmingham evoked "those 'first bright days of Reconstruction. . . [which] gave to our region its first democratic governments.' It was time, he said, for 'history to repeat itself."”260

Instead, however, the SCHW's voting drive was put down by force and fraud. The history southerners and the nation lived and saw only confirmed again that such a southern movement could not prevail without national support. But the national government and the party system from which such support would have had to emerge were too deeply mired in states' rights and white supremacy. The Solid South's ongoing

252. See generally ThOMAs KrUeger, AND Promises to KeEP: THE SOUthern CONFERENCE FOR HUMAN WELFARE, 1938-1948, at 18-19 (1967) (suggesting that both President Roosevelt and the Southern Conference for Human Welfare's founders sought "an informal alliance between the progressive South and the National Administration").

253. Clark H. Foreman \& James Dombrowski, Memo for the CIO Executive Board (Nov. 13, 1944), in Records of THE SOUthern CONFERENCE FOR Human Welfare, Box 43, Tuskegee Institute Archives, quoted in NUMAN BARTLEY, THE NEW SOUTH, 1945-1980, at 24 n.46 (1997).

254. Id.

255. Id.

256. 321 U.S. 649 (1944).

257. Id. at $653-66$.

258. SUlLIVAN, supra note 208 , at $188-89$.

259. Id. at 212, 216.

260. Id. at 191 (quoting Osceola McKaine). 
defeat of Reconstruction and its promise of national civil and political rights ensured the defeat of New Deal social citizenship.

\section{THE 1960s CIVIL Rights MoveMENT AND THE DREAM OF SOCIAL CITIZENSHIP}

The civil rights movement of the 1960s opened the gates of Congress to reform for the first time since the 1930s. ${ }^{261}$ The reforms it gained were epochal - an end to Jim Crow and legal segregation, the enfranchisement of the black South, a raft of federal antidiscrimination statutes, including Title VII of the Civil Rights Act of $1964{ }^{262}$ which outlawed job discrimination, much as the 1940s FEPC measures had aimed to do, and a War on Poverty that funded thousands of community activists and attorneys in the black inner cities to demand welfare rights and equal access to educational and other resources.

What these reforms conspicuously did not achieve was social citizenship as the New Deal era had understood it: not simply the civil right to compete for work free from discrimination, but the social rights to decent work and livelihoods and social insurance for all. Keeping blacks dependent on local labor markets and poor relief was the principal reason for the segmented and caste-ridden system of social provision and labor rights bequeathed by the New Deal. A quarter century later, this system underpinned a fairly robust private welfare state of job security, pensions, and health insurance for organized workers in core sectors of the industrial economy. But that meld of public and private rights excluded most African Americans, whose anger exploded in all the large cities of the North, where millions of southern blacks had moved over the preceding decades to escape Jim Crow and rural unemployment. For them, as for millions of other poor citizens, public assistance, primarily Aid to Families with Dependent Children, stood as the sole federal protection against poverty. Welfare became the terrain on which liberal legal scholars and activists waged their "War on Poverty." ${ }^{63}$ It was this separate, decentralized, and deeply gendered benefits program, stamped with many of the centuries-old degradations of poor relief, that welfare rights organiz-

261. Part III draws heavily on Forbath, supra note 6.

262. Pub. L. No. $88-352, \S 701,78$ Stat. 253 (codified as amended at 42 U.S.C. $\S 2000(\mathrm{e})$ (1994)).

263. Forbath, Constitutional Welfare Rights, supra note 17, at 1822. 
ers, advocates, and attorneys sought to transform into a dignifying right to a guaranteed income. ${ }^{264}$

For their part, however, civil rights leaders had asked not for welfare, but for social citizenship rights. The 1963 March on Washington for Jobs and Freedom and the 1965 Freedom Budget conveyed Martin Luther King, Jr.'s demands. ${ }^{265}$ King's advisor, Bayard Rustin, was a lieutenant of A. Philip Randolph during Randolph's 1941 March on Washington campaign, and King made Rustin chief organizer of the 1963 March on Washington. ${ }^{266}$ In 1964, Rustin warned the Democratic National Convention that the "solution to our full citizenship" demanded more than "the Civil Rights Bill.,"267 "We cannot have fair employment," he told Congress the previous year, "until we have full employment." $" 268$

The continuity of visions of equal citizenship between the early 1960s and New Deal era civil rights movements is plain. The "full emancipation and equality of Negroes and the poor, ${ }^{269}$ King repeatedly told rallies and demonstrations, legislative hearings, and White House conferences, demanded a contemporary social and economic Bill of Rights. King's "Bill," like Roosevelt's, emphasized decent incomes, education, housing, and full employment. ${ }^{270}$ King's "Bill" found programmatic expression in the Freedom Budget for All Americans. ${ }^{271}$ King and New

264. See id. at 1822-23 (noting that the context in which the War on Poverty was declared was the result of "earlier efforts to institute a more substantive and 'social' conception of citizenship rights").

265. DAVID J. GARROW, BEARING THE CROSs 284 (1986); Forbath, supra note 6, at 87.

266. GARROW, supra note 265, at 277.

267. Bayard Rustin, Address to Democratic National Convention, Atlantic City, N.J. (Aug. 1964), reprinted in BAYARD RUSTIN PAPERS, Reel 3, at 27, quoted in Forbath, supra note 6, at 86 n. 381 .

268. Id., Reel 4, at 7, quoted in Forbath, supra note 6, at 87 n.387.

269. Martin Luther King, JR., Where Do We Go from Here: Chaos or COMMUNITY 193 (1967).

270. Id. at 193-202. King underscored the class-based character of his bill. "Any "Negro Bill of rights,"” he wrote,

based upon the concept of compensatory treatment as a result of the years of cultural and economic deprivation resulting from racial discrimination... must give greater emphasis to the alleviation of economic and cultural backwardness on the part of the so-called "poor white." It is my opinion that many white workers whose economic condition is not too far removed from the economic condition of his black brother, will find it difficult to accept a "Negro Bill of Rights," which seeks to give special consideration to the Negro in the context of unemployment, joblessness, etc. and does not take into sufficient account their plight (that of the white worker).

GARRow, supra note 265, at 312 (quoting King).

271. Bayard Rustin, Untitled Article on the Freedom Budget (circa Dec. 1965), in BAYARD RUSTIN PAPERS, Reel 13, at 1, cited in Forbath, supra note 6, at 87 n.390. 
Deal-era civil rights and labor leader A. Philip Randolph proposed the Freedom Budget as a "multi-billion dollar social investment to destroy the racial ghettoes of America, decently house both the black and white poor, and to create full and fair employment in the process.",272 Randolph compared the idea to the "social investments of the New Deal." 773 The New Deal "evoked a new psychology of citizenship" among white workers. ${ }^{274}$ The Freedom Budget aimed to do likewise "among millions of Negroes." years late." 276

The full employment and social investment policies proposed in the Freedom Budget found support elsewhere-in the labor movement and the Johnson administration. Johnson's Secretary of Labor, Willard Wirtz, attacked the "partial and piecemeal" social services and work counseling approach being adopted by the War on Poverty. ${ }^{277}$ Wirtz and his colleagues in the Labor Department were tracking the "human slag heap" that had begun to emerge in the nation's industrial regions, including its central cities where black unemployment had begun to "explode." Instead of the War on Poverty approach, with its emphasis on welfare and community action, Wirtz urged regional and sectoral public investment, other incentives for job creation, and coordinated employment services and training. ${ }^{278}$

Although Congress enacted Title VII of the 1964 Civil Rights Act to address employment discrimination, the Freedom Budget and full employment ideas foundered. Contemporaries explained their defeats in terms of the mounting costs of the Vietnam War and Lyndon B. Johnson's desire for a cheap quick fix for ghetto unrest. The reasons were deeper. The defeat of full employment commitments after World War II meant that unemployment persisted in America, often reaching depression levels in inner cities, rural regions, and the Midwest's new Rust Belt. Unemployment became, once more, a fixed condition, a fact

272. Id., quoted in Forbath, supra note 6, at 87 n.390.

273. Id. at 9, quoted in Forbath, supra note 6, at 87 n.390.

274. Id., quoted in Forbath, supra note 6, at 87 n.390.

275. Id., quoted in Forbath, supra note 6, at 87 n.390.

276. Id. at 8-9, quoted in Forbath, supra note 6, at 87 n.390.

277. Memorandum from Willard Wirtz to Walter Heller (Nov. 19, 1963), in ADMINISTRATIVE History OF THE DEPARTMENT OF LABOR, Documentary Supplement, Sec. III-B, Box 12, Lyndon B. Johnson Presidential Library, cited in Forbath, supra note 6, at 88 n.394.

278. Id.; see also Margaret Weir, The Federal Government and Unemployment: The Frustration of Policy Innovation from the New Deal to the Great Society, in PoLITICS, supra note 183, at 149, 170-71 (stating that Wirtz was a "major force within the administration pushing for increased federal support for selective interventions to boost employment"). 
of nature. The echoes of New Deal full employment rhetoric in the pronouncements of Democrats rang hollow in the political context of the 1960s.

Committing the Democrats to the costly public investments and full employment priorities that King demanded, and the New Deal liberals in Congress endorsed in principle, would have required mobilization and coalition-building on a much vaster scale than the civil rights movement. Perhaps a mobilized labor movement combined with civil rights forces would have been sufficient to compel Johnson and Congress to act, and business elites to acquiesce. But such a conjuncture was not in the cards. The United Automobile Workers' president Walter Reuther and other progressive labor leaders supported King and Wirtz's visions, but the AFL-CIO leadership and Reuther's own autoworker constituents did not. ${ }^{279}$ The defeats social citizenship suffered in the late 1930s and early 1940s, when the whole industrial union movement demanded it, meant that the language of social citizenship no longer resonated for organized workers.

\section{CONCLUSION}

The New Deal Constitution of social citizenship remains in exile. What is left is a judicial Constitution that constrains congressional enforcement of its human rights provisions according to limits set by late-nineteenth-century precedent. The roots of these constraints lie in the jurisdictional compromise struck by the New Dealers: resting the "fundamental rights" of the Wagner Act on the Commerce Clause to avoid conflict with the Court's interpretation of the Reconstruction Amendments' provisions affirming the rights of free labor. A few trade union leaders tried to persuade Wagner to rest his Labor Disputes Act on the Thirteenth Amendment, to force the Court to uphold the Act, if it would, in a fashion that tied labor's statutory rights to the rights doctrines of the Court's Constitution. These old trade unionists understood the virtues of formal foundations, not only in the courts but also in public discourse. But Wagner, his counselors, and the more "progressive" wing of the labor movement thought differently about labor's rights. Labor rights were contextual and changing and also affirmative and de-

279. See, e.g., LiCHTENSTEIN, supra note 215, at 404-15; Thomas J. Sugrue, Crabgrass Roots Politics: Race, Rights, and the Reaction Against Liberalism in the Urban North, 1940-1964, 82 J. AM. HIST. 551, 571 (1995) (noting that, because of "racial resentment and homeowners' politics," over two-thirds of the United Automobile Workers' members who voted in Detroit's mayoral election of 1949 did not vote for the United Automobile Workers-backed liberal candidate). 
pendent on positive protection and enforcement. All things equal, it would have been well to rest them on the Reconstruction Amendments, but all things were not equal. Wagner therefore chose a path for the political Constitution that left labor's freedoms afloat on the sea of politics, believing that, in any case, positive social and economic rights had to be safeguarded and sustained in the currents of political life.

Wagner prevailed, and the political Constitution and its legislative conception of fundamental rights seemed vindicated in the public sphere, in the labor movement, and in the courts. However, the Court's "switch in time" brought an unanticipated change in the politicalconstitutional landscape. The Court dismantled the old "Republican" Constitution's barriers to Democratic reform, but then the northern Democrats who strove to complete the New Deal "revolution" by enacting its promised social rights into law confronted bitter adversaries in the Dixiecrats who continued to uphold states' rights. The latter forged a conservative coalition with congressional Republicans, and between them, they took up the banners of the old Constitution in the halls of Congress. Southern Bourbons and Northern probusiness Republicans waged a counterrevolution that defeated the New Deal project of redefining national citizenship.

White America and the federal government's abandonment of Reconstruction did more than deprive black Americans of civil and political rights for almost another century. By allowing the emergence and consolidation of the Solid South, this constitutional bad faith prevented all Americans from securing the boon of social citizenship. From the perspective of this history, the New Deal constitutional legacy that is under attack today by restorationist scholars and judges is a marred one. The vast expansion of national governmental power has been constitutionally enshrined, but the reason for its expansion has not.

Nevertheless, this history may yield a constitutional imperative that binds citizens and lawmakers, the true authors and interpreters of the political Constitution. If this history proves persuasive, then perhaps the New Deal constitutional revolution was left unfinished. Its expansion of national authority rested on an unkept promise, and the fate of this promise of social citizenship was decided by the nation and government's complicity with Jim Crow. If I am right about these historical matters, then the question of social citizenship was concluded illegitimately and must be reopened. Even further, those who defend the main contours of congressional power under the New Deal Constitution may be obliged to make good faith efforts to enact the social citizenship 
rights it promised. The Court will not do anything to mend the broken constitutional links between racial and economic justice, but we can.

And that, finally, improbably, returns me to Judge Douglas Ginsburg. Judge Ginsburg and other conservatives are right to revive scholarship and debate about constitutional political economy. But where they see economic liberty and constitutional property rights through the Lochner tradition, I see them through the progressive, social citizenship tradition. Their call is chiefly for strenuously active right-wing courts; mine for conscientious lawmakers and citizens. Liberals must join issue with the restorationists not simply by defending a broader conception of national power, but by renewing and reimagining the forgotten and exiled citizenship rights of the New Deal Constitution. 